STATUS OF GROUND-WATER RESOURCES AT U.S. NAVY SUPPORT FACILITY, DIEGO GARCIA: SUMMARY OF HYDROLOGIC AND CLIMATIC DATA, JANUARY 1992 THROUGH JUNE 1994

U.S. GEOLOGICAL SURVEY

Open-File Report 94-479

Prepared in cooperation with the

U.S. DEPARTMENT OF THE NAVY

NAVY SUPPORT FACILITY, DIEGO GARCIA 
STATUS OF GROUND-WATER RESOURCES AT U.S. NAVY SUPPORT FACILITY, DIEGO GARCIA: SUMMARY OF HYDROLOGIC AND CLIMATIC DATA, JANUARY 1992 THROUGH JUNE 1994 by Jill D. Torikai

U.S. GEOLOGICAL SURVEY

Open-File Report 94-479

Prepared in cooperation with the U.S. DEPARTMENT OF THE NAVY NAVY SUPPORT FACILITY, DIEGO GARCIA 


\section{U.S. DEPARTMENT OF THE INTERIOR \\ BRUCE BABBITT, Secretary}

\section{U.S. GEOLOGICAL SURVEY}

Gordon P. Eaton, Director

Any use of trade, product, or firm names in this publication is for descriptive purposes only and does not imply endorsement by the U.S. Government.

For sale by the U.S. Geological Survey

Earth Science Information Center

Open-File Reports Section

Box 25286, MS 517

Denver Federal Center

Denver, CO 80225

For additional information write to:

District Chief

U.S. Geological Survey

677 Ala Moana Blvd., Suite 415

Honolulu, HI 96813 


\section{CONTENTS}

Executive Summary

Introduction

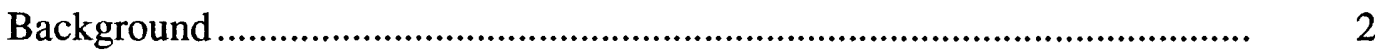

Organization of Report ................................................................................. 2

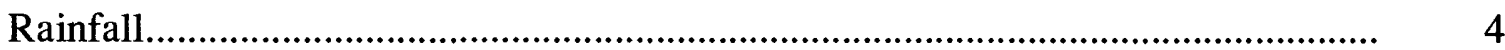

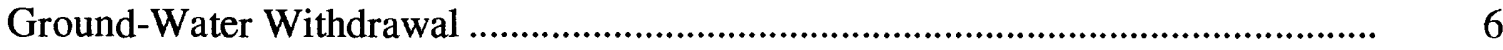

Chloride Concentration of Pumped Ground Water ......................................................

Chloride Concentration of Ground Water in Monitoring Wells.................................. 11

Fuel-Diversion Program at Air Operations................................................................. 14

Hydrologic-Data Section A. Maps of Production and Monitoring Wells at Cantonment and Air Operations ...................................................................... 17

Hydrologic-Data Section B. Graphs of Monthly Mean Ground-Water Withdrawal,

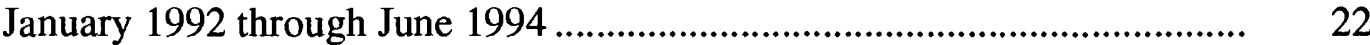

Hydrologic-Data Section C. Graphs of Weekly Chloride Concentration of Pumped Water, January 1992 through June 1994 ............................................. 33 


\section{FIGURES}

1. Map showing areas of ground-water production, Diego Garcia.............................. 3

2. Graphs of monthly rainfall and monthly departure from mean rainfall at Air Operations, Diego Garcia, January 1992 through June 1994.

3. Graphs of monthly mean ground-water withdrawal islandwide and in the ground-water production areas, Diego Garcia, January 1992 through June 1994

4. Graphs of weekly chloride concentration of pumped water in the ground-water production areas, Diego Garcia, January 1992 through June 1994 ................

5. Graphs of monthly chloride concentration of ground water in monitoring wells at site AW16 at Cantonment, Diego Garcia, January 1992 through June 1994

6. Graphs of monthly chloride concentration of ground water in monitoring wells at site BW09 at Air Operations, Diego Garcia, January 1992 through June 1994

7. Graphs of monthly mean ground-water withdrawal and injection at wells AO-10 through AO-15 at Air Operations, Diego Garcia, January 1992 through June 1994

\section{TABLE}

1. Target and actual withdrawal and injection rates for hydraulic-diversion 


\section{CONVERSION FACTORS AND ABBREVIATION}

\begin{tabular}{|c|c|c|}
\hline Multiply & By & To obtain \\
\hline foot $(\mathrm{ft})$ & 0.3048 & meter \\
\hline gallon (gal) & 3.785 & liter \\
\hline gallon per day (gal/d) & 3.785 & liter per day \\
\hline million gallons per day (Mgal/d) & 0.04381 & cubic meter per second \\
\hline inch (in.) & 25.4 & millimeter \\
\hline inch per year (in/yr) & 25.4 & millimeter per year \\
\hline
\end{tabular}

Abbreviation used in water-quality descriptions

$\mathrm{mg} / \mathrm{L}=$ milligram per liter 


\section{STATUS OF GROUND-WATER RESOURCES AT \\ U.S. NAVY SUPPORT FACILITY, DIEGO GARCIA: \\ SUMMARY OF HYDROLOGIC AND CLIMATIC DATA, JANUARY 1992 THROUGH JUNE 1994}

\section{EXECUTIVE SUMMARY}

This report contains hydrologic and climatic data that describe the status of ground-water resources at U.S. Navy Support Facility, Diego Garcia. Data are presented from January 1992 through June 1994. This report concentrates on data from 1994, and references historic data from 1992 and 1993.

1. RAINFALL--Total rainfall for the first half of 1994 was 51 inches which is 48 percent of the mean annual rainfall of 106 inches. In comparison, total rainfall for the first six months of 1993 and 1992 was 56 inches and 51 inches, respectively. Annual rainfall totals in 1993 and 1992 were 95 inches and 93 inches, respectively.

2. GROUND-WATER WITHDRAWAL--Ground-water withdrawal has averaged 975,000 gallons per day through June 1994, while withdrawals in 1993 and 1992 averaged 954,000 gallons per day and 936,000 gallons per day, respectively. In each of the five areas of groundwater production, withdrawals have remained steady since 1991.

3. CHLORIDE CONCENTRATION OF PUMPED WATER--At the end of June 1994, the chloride concentration of the composite water supply was 68 milligrams per liter, well below the 250 milligrams per liter secondary drinking water standard established by the U.S.

Environmental Protection Agency. Chloride concentrations of the composite water supply from January through June 1994 ranged between 37 and 90 milligrams per liter.

\section{CHLORIDE CONCENTRATION OF GROUND WATER IN MONITORING WELLS--} Chloride concentration of ground water in monitoring wells at Cantonment and Air Operations have increased very slightly since March 1994 coinciding with the start of the dry season. There has been a general trend of increasing chloride concentrations in the deeper monitoring wells since the 1992 dry season, which began in March 1992.

5. FUEL-DIVERSION PROGRAM--A fuel spill at Air Operations caused the shutdown of ten wells in May 1991. Four of the wells resumed pumping for water-supply purposes in April 1992. The remaining six wells are being used to hydraulically contain and divert fuel migration. 


\title{
STATUS OF GROUND-WATER RESOURCES AT \\ U.S. NAVY SUPPORT FACILITY, DIEGO GARCIA: SUMMARY OF HYDROLOGIC AND CLIMATIC DATA, JANUARY 1992 THROUGH JUNE 1994
}

\author{
By Jill D. Torikai \\ INTRODUCTION
}

\section{Background}

Diego Garcia Atoll is a British Indian Ocean Territory and the site of a U.S. Navy Support Facility. The island's drinking-water supply is derived from ground water by a system of more than 100 shallow wells from five production areas (fig. 1). Pumped water from the Cantonment and Air Operations areas combined account for about 99 percent of the total island pumpage. The remainder is pumped for local use at Industrial Site South, Transmitter Site, and GEODSS Site. The system has been in operation since 1978 and has provided about $1 \mathrm{Mgal} / \mathrm{d}$ since 1984.

Long-term ground-water management is facilitated by a cooperative agreement between the Navy Support Facility and the U.S. Geological Survey (USGS). The Diego Garcia LongTerm Ground-Water Management Program involves data collection and analysis of daily rainfall, daily pumpage for individual wells, and chloride concentrations of water from all production and monitoring wells. The data are stored in a computerized database and analyzed for hydrologic responses to pumping and climatic variability. This report summarizes recent hydrologic events and identifies trends in the data.

\section{Organization of Report}

This data summary contains hydrologic and climatic data that describe the status of ground-water resources at Navy Support Facility, Diego Garcia. Data presented are from January 1992 through June 1994. Data of primary relevance to the water supply are:

1. Rainfall

2. Volume of ground water withdrawn by production wells

3. Chloride concentration of the pumped water

4. Chloride concentration of ground water sampled from monitoring wells

5. Volume of ground water injected at Air Operations

The narrative that follows highlights recent trends in the data for the first half of 1994. Groundwater withdrawal and chloride concentrations of water from individual wells are presented in the "Hydrologic-Data Section" at the end of this summary. The data section contains the following:
A. Maps of production and monitoring wells at Cantonment and Air Operations
B. Graphs of monthly mean ground-water withdrawal, January 1992 through June 1994
C. Graphs of weekly chloride concentration of pumped water, January 1992 through June 1994 


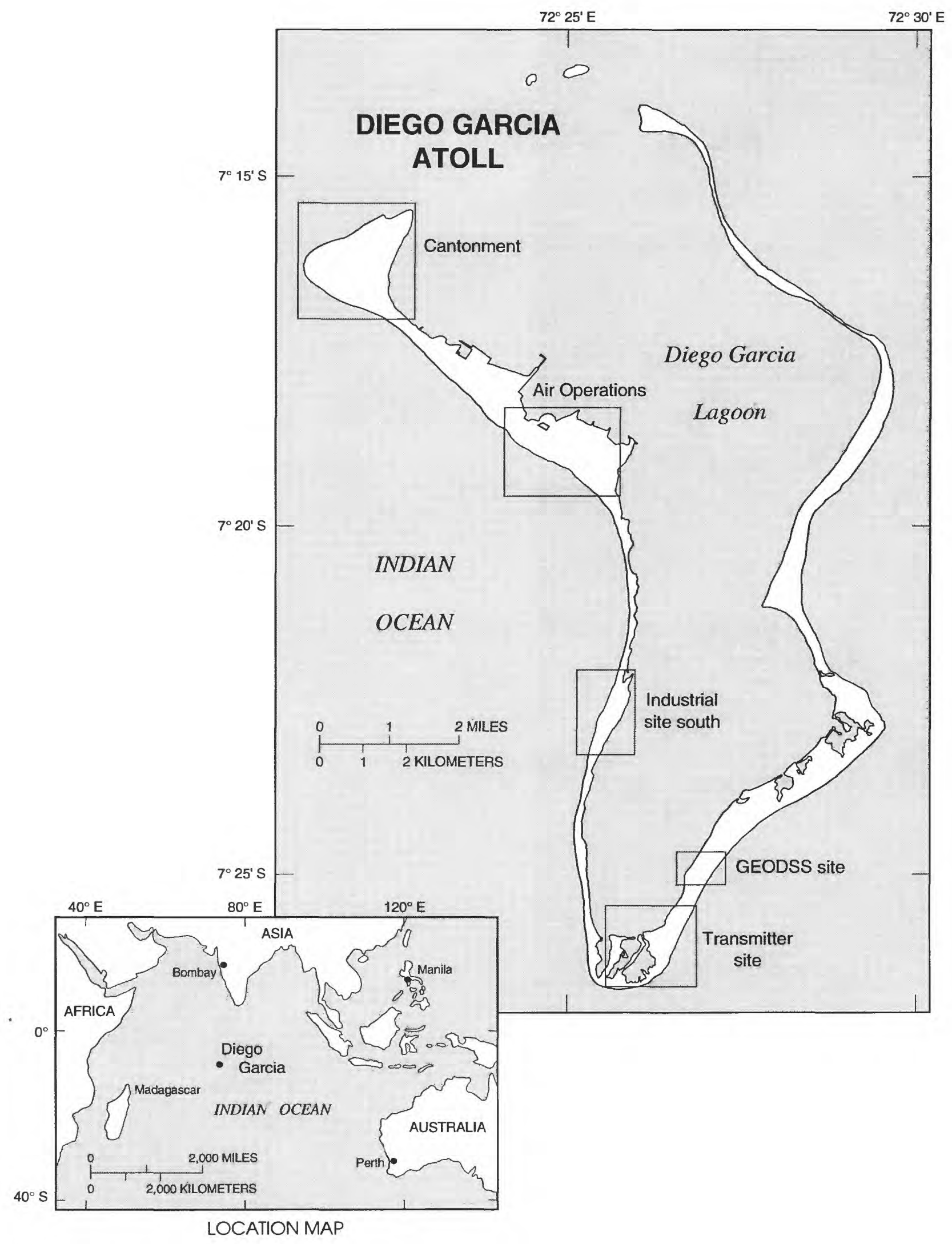

Figure 1. Areas of ground-water production, Diego Garcia. 


\section{RAINFALL}

Background.--The mean annual rainfall at Diego Garcia for the fixed base period 1951-90 is $105.73 \mathrm{in} / \mathrm{yr}$, with considerable month-to-month and year-to-year variability. A wet season occurs from about September through February, and a dry season occurs from about March through August.

Recent trends.--Total rainfall for the first half of 1994 was 50.64 inches which is 48 percent of the mean annual of 105.73 inches. At mid-year of 1993 and 1992, total rainfall was 56 inches and 51 inches, respectively. In both those years, total rainfall was below the mean annual rainfall: 94.77 inches or 10 percent below the mean in 1993, and 92.99 inches or 12 percent below the mean in 1992. Low rainfall has been recorded since 1992 and has continued thus far in 1994.

Negative or near-zero values in the smoothed rainfall departures have persisted since March 1992 (fig. 2). Positive departures occurred briefly from December 1993 through February 1994 during which the three-month cumulative rainfall was 39 inches. The 1994 dry season began in March and rainfall has decreased since the start of the year. Negative values in the smoothed departures from mean rainfall for the period April through June 1994 are larger than the negative departures for the same months from the two prior years. Prominent negative departures have occurred in 1984, 1985, and 1989, and have corresponded with documented periods of freshwater lens shrinkage, saltwater intrusion, and increased chloride concentration of pumped water (C.D. Hunt, U.S. Geological Survey, written commun., 1993). 


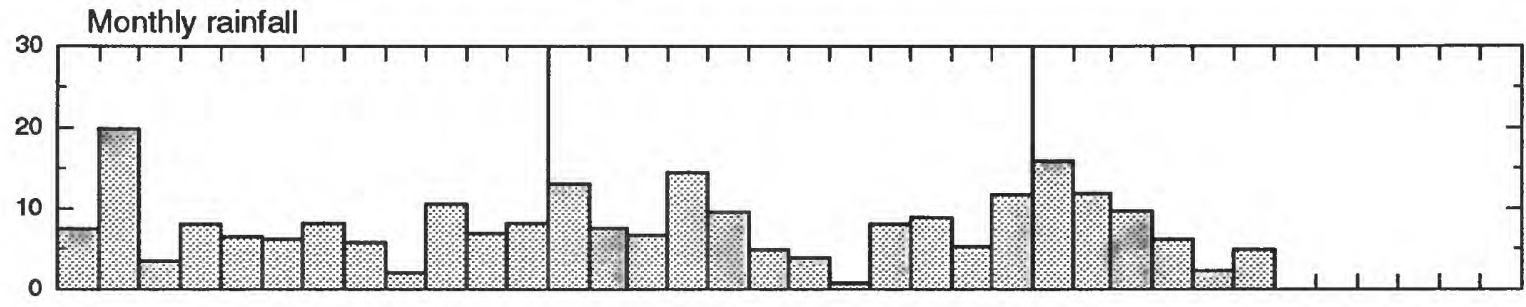

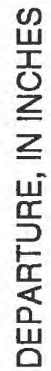

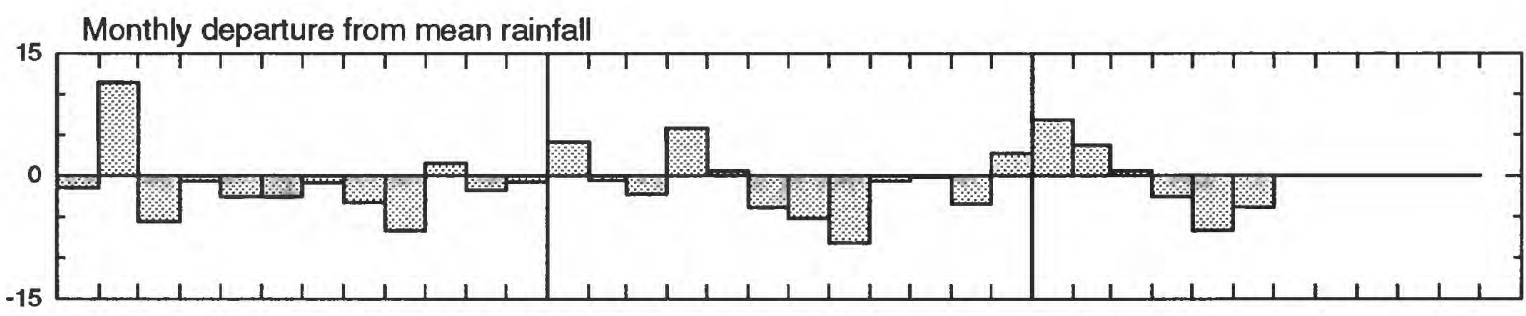

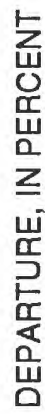

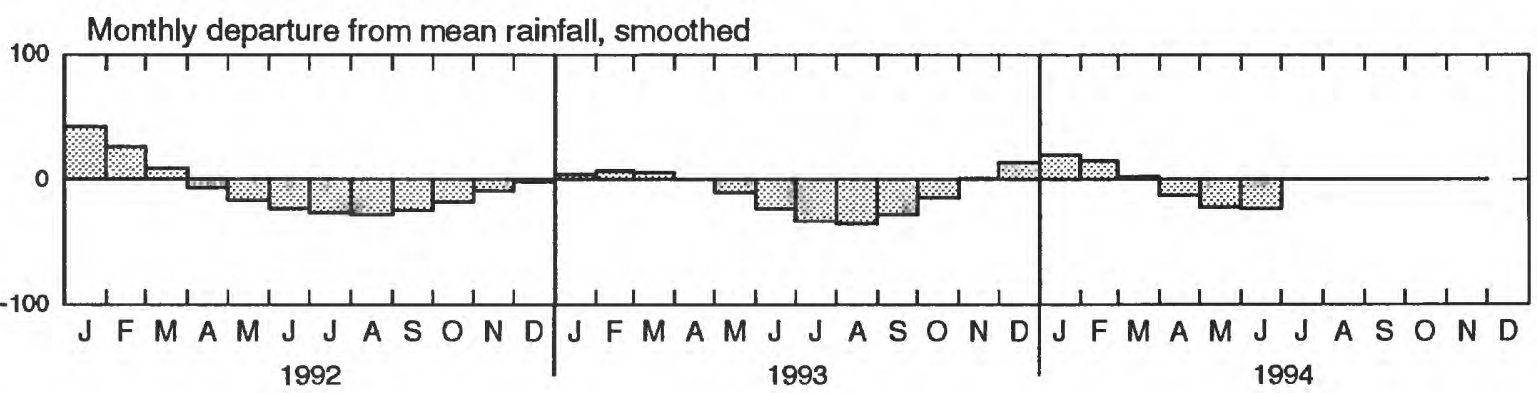

Figure 2. Monthly rainfall and monthly departure from mean rainfall at Air Operations, Diego Garcia, January 1992 through June 1994. Mean rainfall, in inches per month, is the mean annual rainfall divided by 12 . Smoothed monthly departure from mean rainfall is calculated with an 11-point, center-weighted, moving average filter with weighting factors that approximate the normal probability distribution. 


\section{GROUND-WATER WITHDRAWAL}

Background.--Withdrawal is measured by flow meters at all production wells and storage tanks in the water system, and is recorded daily. There are 102 production wells that are situated in five ground-water production areas, of which 80 wells are in the Cantonment area. The wells in the Cantonment area are further divided into sub-groups, and the measured groundwater withdrawals are reported as such in this summary.

Recent trends.--Figure 3 shows time series of monthly mean withdrawal islandwide and in each ground-water production area from January 1992 through June 1994. Patterns of withdrawal in 1994 have not changed appreciably from prior years in all areas. Total islandwide

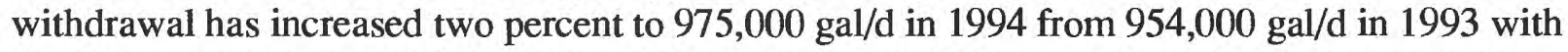
the Cantonment area supplying most of the extra demand. Pumpage from the Cantonment area has also increased since 1991 because of the May 1991 through April 1992 closure of 10 Air Operations wells due to a fuel spill near those wells. Six Air Operations wells still do not pump to the water supply because of the fuel spill. 


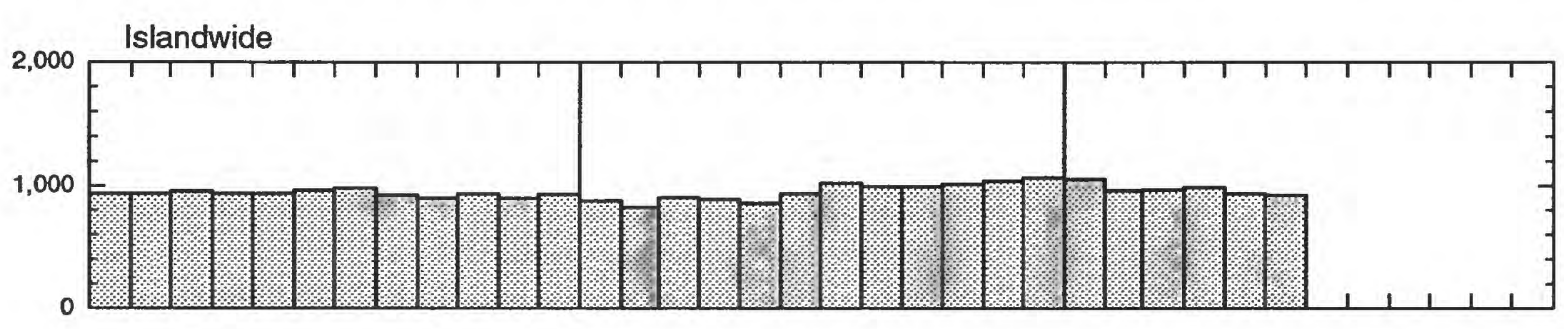

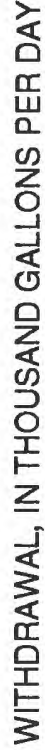
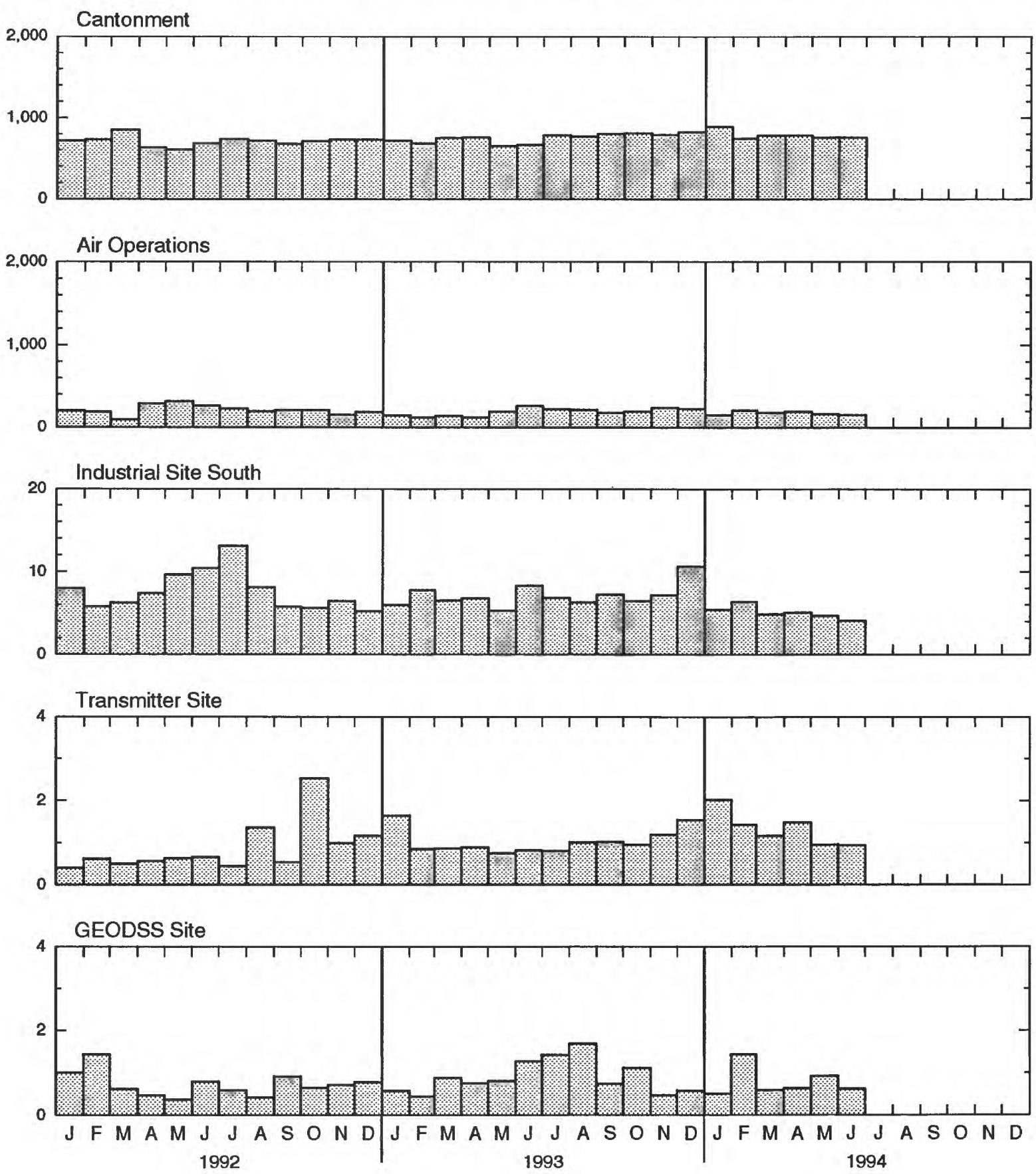

Figure 3. Monthly mean ground-water withdrawal islandwide and in the ground-water production areas, Diego Garcia, January 1992 through June 1994. 


\section{CHLORIDE CONCENTRATION OF PUMPED GROUND WATER}

Background.--The chloride concentration is used as a quantitative measure of salinity in this summary. Chloride concentration in seawater at Diego Garcia is about $19,500 \mathrm{mg} / \mathrm{L}$ whereas a concentration of $250 \mathrm{mg} / \mathrm{L}$ is the maximum contaminant level (MCL) under secondary drinking-water standards established by the U.S. Environmental Protection Agency. Secondary standards are not enforceable limits, but instead establish goals for constituents that may affect the aesthetic qualities of drinking water, such as taste or color.

Water is sampled weekly at all wells and storage tanks in the production system. Water in the Air Operations tank is a blend of ground water withdrawn from wells in the Air Operations area only, whereas the Cantonment tank is a mixture of ground water from wells in both the Air Operations and Cantonment areas. This composite tank stores about 99 percent of total, islandwide pumpage. Thus, the chloride concentration of water sampled from the Cantonment tank is considered representative of the overall water supply.

Recent trends.--The chloride concentration of the composite water supply at the end of June 1994 was $68 \mathrm{mg} / \mathrm{L}$, well below the $250 \mathrm{mg} / \mathrm{L}$ secondary drinking water standard. The range of chloride concentrations for the composite water supply ranged from 37 to $90 \mathrm{mg} / \mathrm{L}$ for the first half of 1994. Chloride concentrations of the composite water in the Cantonment tank has remained at less than $100 \mathrm{mg} / \mathrm{L}$ since 1992 (fig. 4). Chloride concentrations of water sampled from Industrial Site South and Transmitter Site are 100 to $300 \mathrm{mg} / \mathrm{L}$, and about $100 \mathrm{mg} / \mathrm{L}$ at GEODSS Site. Chloride concentrations from these three ground-water production areas commonly fluctuate about $100 \mathrm{mg} / \mathrm{L}$ each month.

Chloride concentration of water in well $\mathrm{H} 7$ at Cantonment has increased from less than $30 \mathrm{mg} / \mathrm{L}$ in 1992 to nearly $80 \mathrm{mg} / \mathrm{L}$ in June 1994 . A persistent trend of increasing chloride concentration in well $\mathrm{H} 7$ has been recorded for the period of record that began in April 1991 (see fig. C2 in the Hydrologic-Data Section, p. 36). 


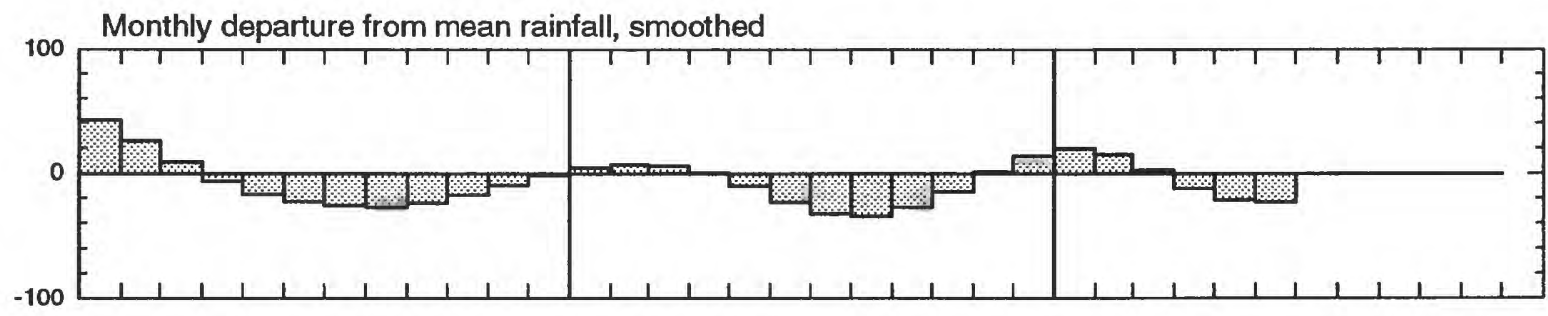

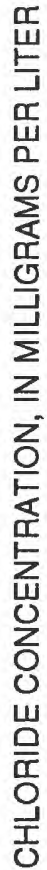
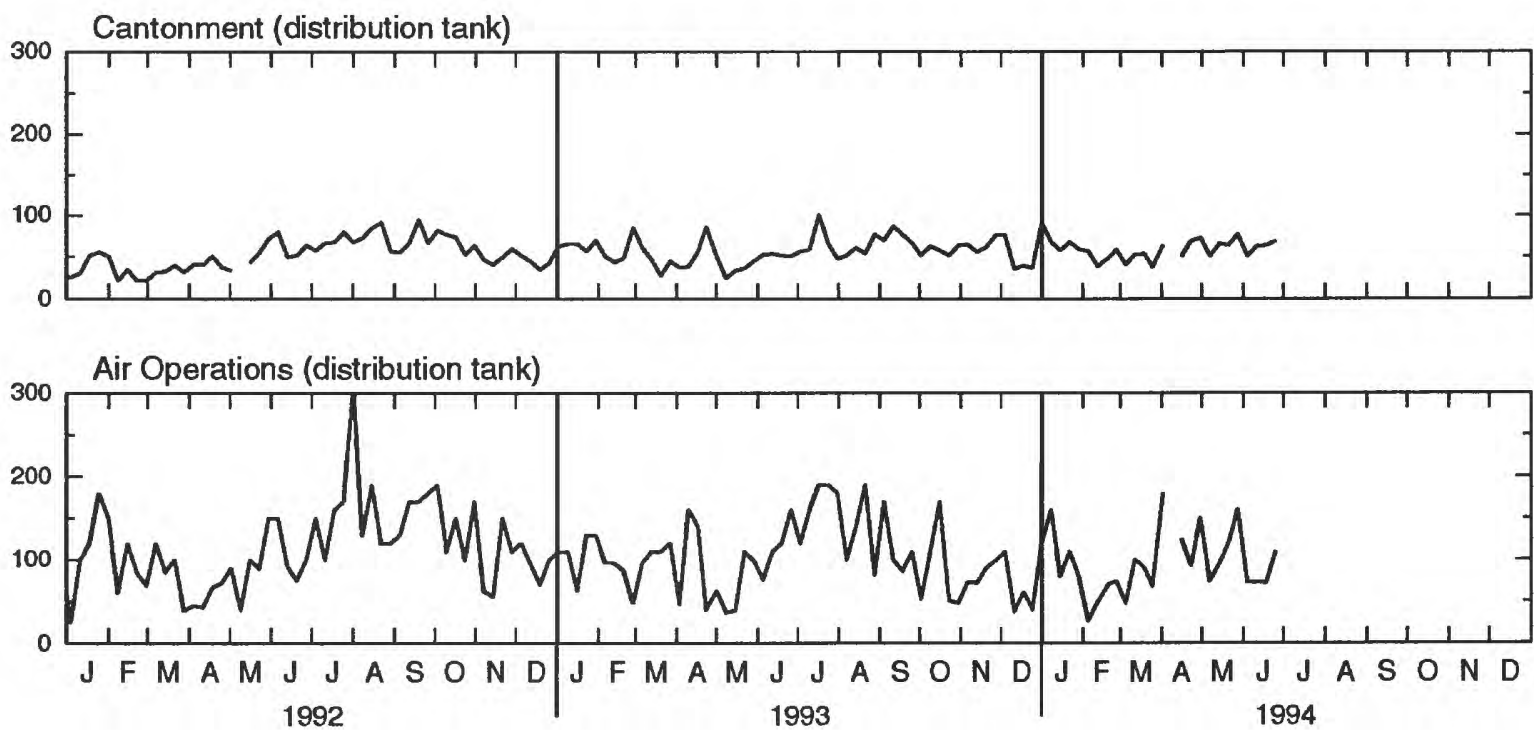

Figure 4. Weekly chloride concentration of pumped water in the ground-water production areas, Diego Garcia, January 1992 through June 1994. Rainfall departure data are shown for comparison. 

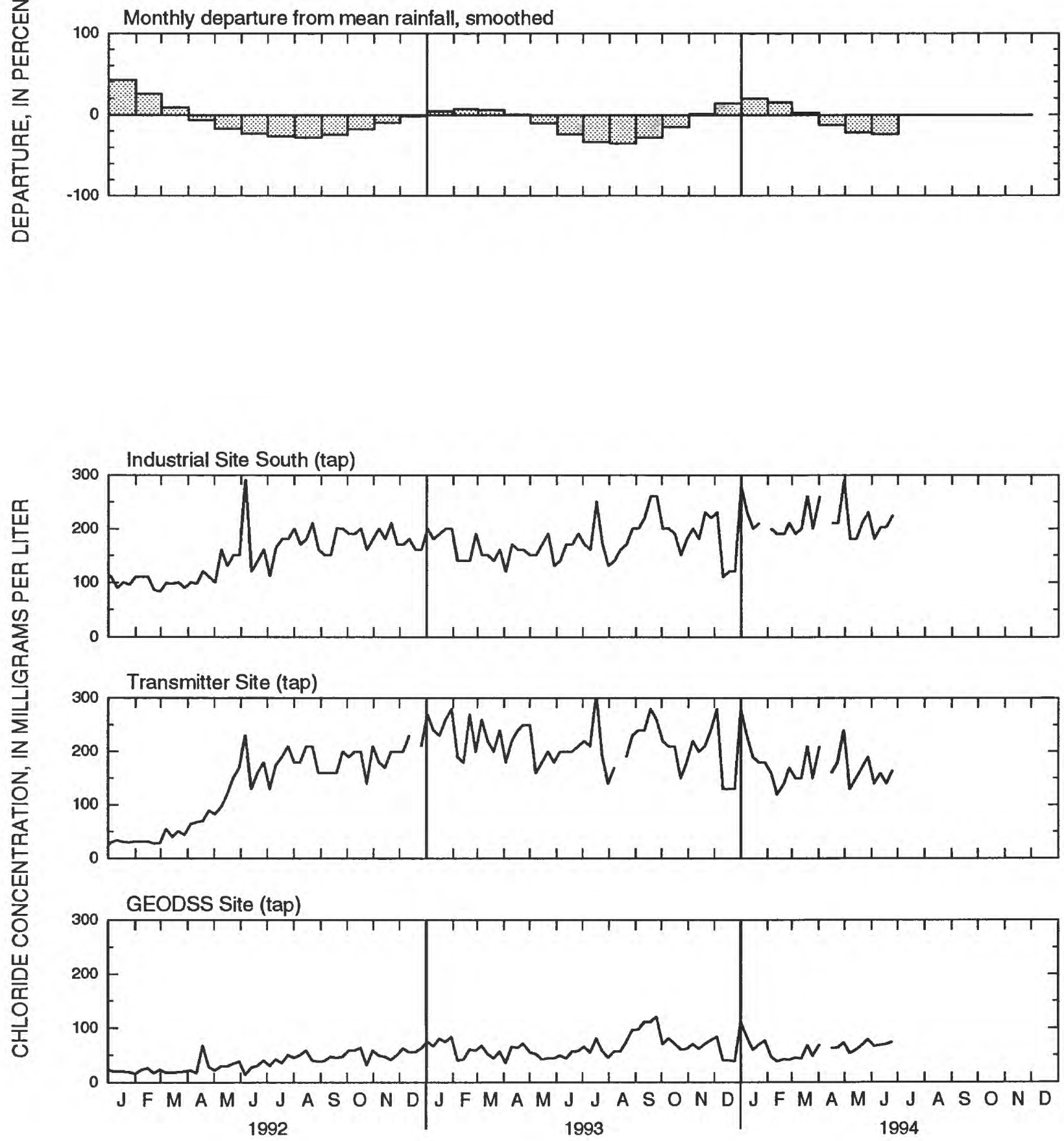

Figure 4 continued.--Weekly chloride concentration of pumped water in the ground-water production areas, Diego Garcia, January 1992 through June 1994. Rainfall departure data are shown for comparison. 


\section{CHLORIDE CONCENTRATION OF GROUND WATER IN MONITORING WELLS}

Background.--Ground-water chloride concentration is measured monthly at 35 monitoring-well sites. Each site comprises several wells, with each well having a short screened (open) interval that bottoms at a different depth. The deeper wells typically tap the freshwatersaltwater mixing zone that underlies the freshwater lenses.

Recent trends.--Monitoring sites AW16 and BW09 have been selected to show trends in ground-water chloride concentration at Cantonment and Air Operations Areas, respectively. Figures 5 and 6 show time series of chloride concentration at different depths at these sites, with smoothed rainfall departures included in the figures for climatic reference. Chloride concentrations of the water increased at both sites during the 1994 dry season that began in March. The increases in chloride concentration tend to be larger with increased depth of the well. 

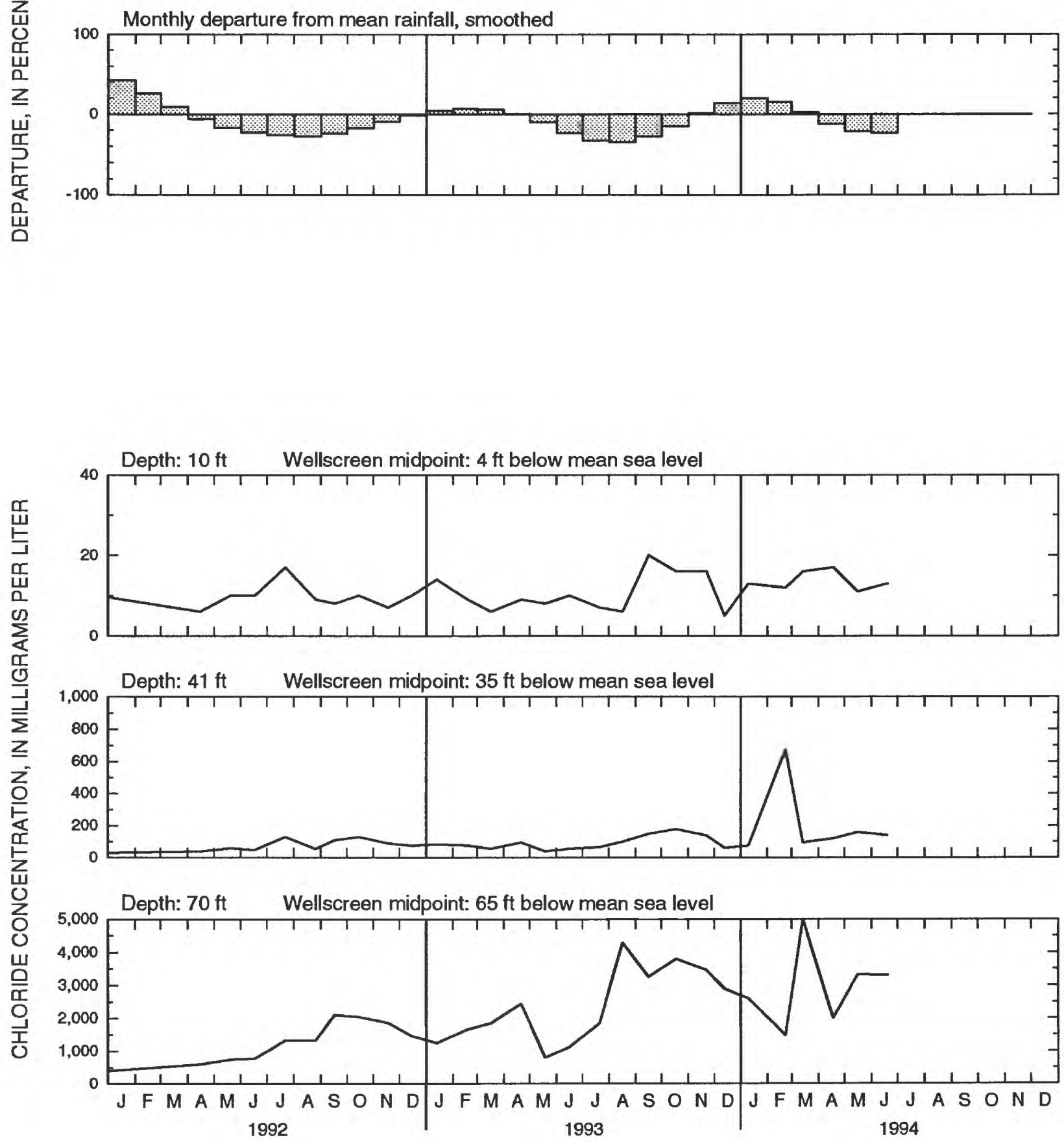

Figure 5. Monthly chloride concentration of ground water in monitoring wells at site AW16 at Cantonment, Diego Garcia, January 1992 through June 1994. Rainfall departure data are shown for comparison. 

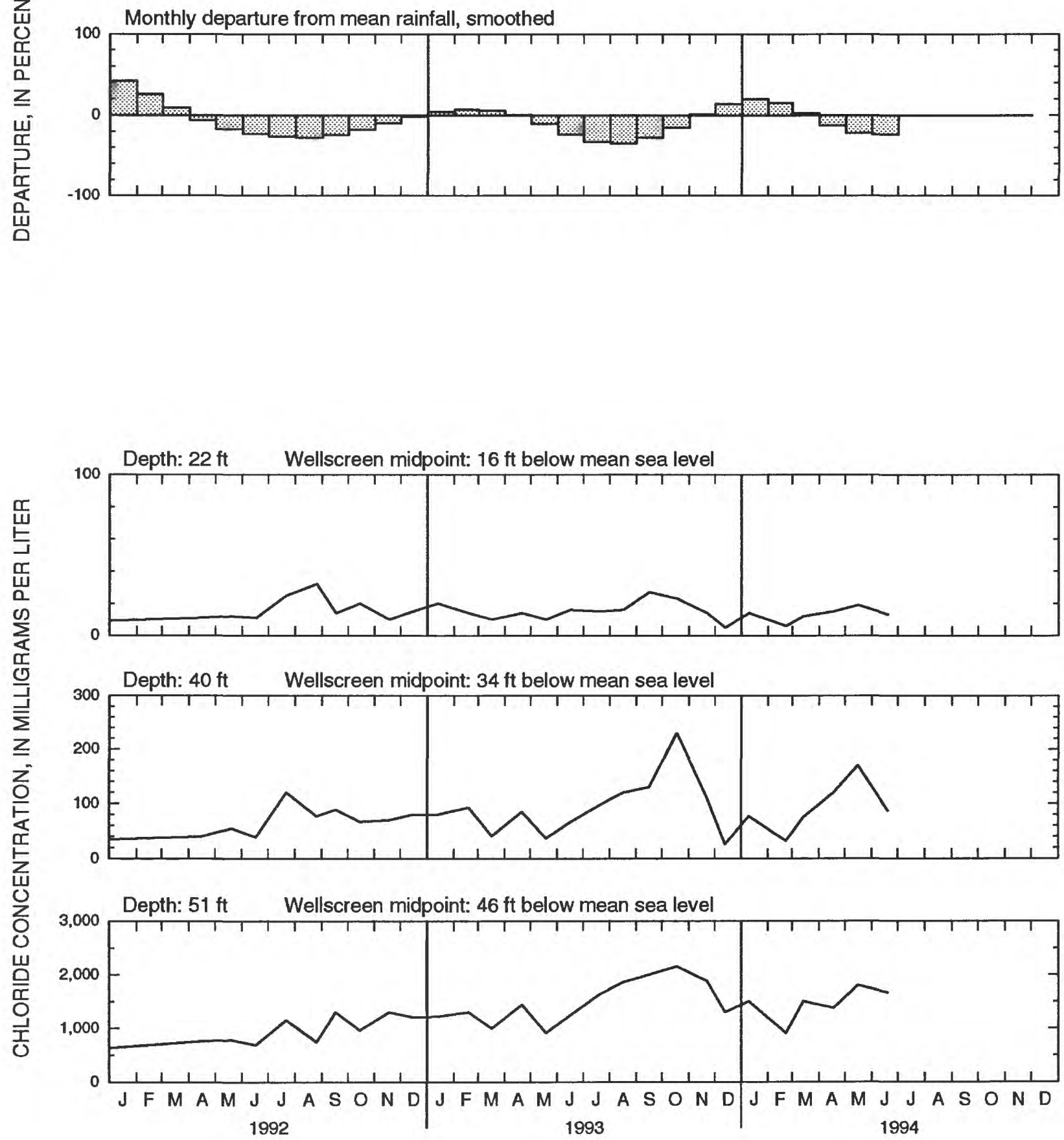

Figure 6. Monthly chloride concentration of ground water in monitoring wells at site BW09 at Air Operations, Diego Garcia, January 1992 through June 1994. Rainfall departure data are shown for comparison. 


\section{FUEL-DIVERSION PROGRAM AT AIR OPERATIONS}

Background.--The normal pattern of ground-water withdrawal at Air Operations has been disrupted since May 1991 by a jet-fuel spill at the South Ramp Parking Apron (fig. A2). In April 1992, a program was initiated to hydraulically divert fuel away from the production wells. The fuel-diversion program consists of pumping water from wells AO-14 and $\mathrm{AO}-15$ and directing this water through the common collection main to the wells nearest the spill (AO-10, 11,12 ), where it is injected back into the aquifer. Wells AO-10 through AO-15 were shut down from May 1991 to April 1992, but have since been used in the closed recirculation loop of withdrawal and injection.

Injection data for wells AO-10, 11, 12 from May 10, 1993 through June 1994 are actual water-meter readings. From April 1992 through early May 1993, meter readings of injection were not available, and daily injection at each of the three wells was estimated to be one-third of the total daily withdrawal from wells AO-13, 14, 15 which provided the injection-supply water. Monthly mean withdrawal and injection at wells AO-10 through AO-15 are shown in figure 7.

Recent trends.--Withdrawal and injection rates for the hydraulic-diversion program are based on target rates for wells AO-10 through AO-15, with total water recirculation of 150,000 $\mathrm{gal} / \mathrm{d}($ table 1).

Table 1. Target and actual withdrawal and injection rates for hydraulic-diversion program. [Injection is denoted by negative values; all values are in gallons per day.]

\begin{tabular}{ccc}
\hline Well & Target rates & $\begin{array}{c}\text { Daily mean rates in } \\
\text { April through June 1994 }\end{array}$ \\
\hline AO-10 & $-30,000$ & $-33,567$ \\
AO-11 & $-50,000$ & $-45,354$ \\
AO-12 & $-70,000$ & $-62,453$ \\
AO-13 & 0 & 0 \\
AO-14 & 70,000 & 69,074 \\
AO-15 & 80,000 & 80,644 \\
\hline
\end{tabular}




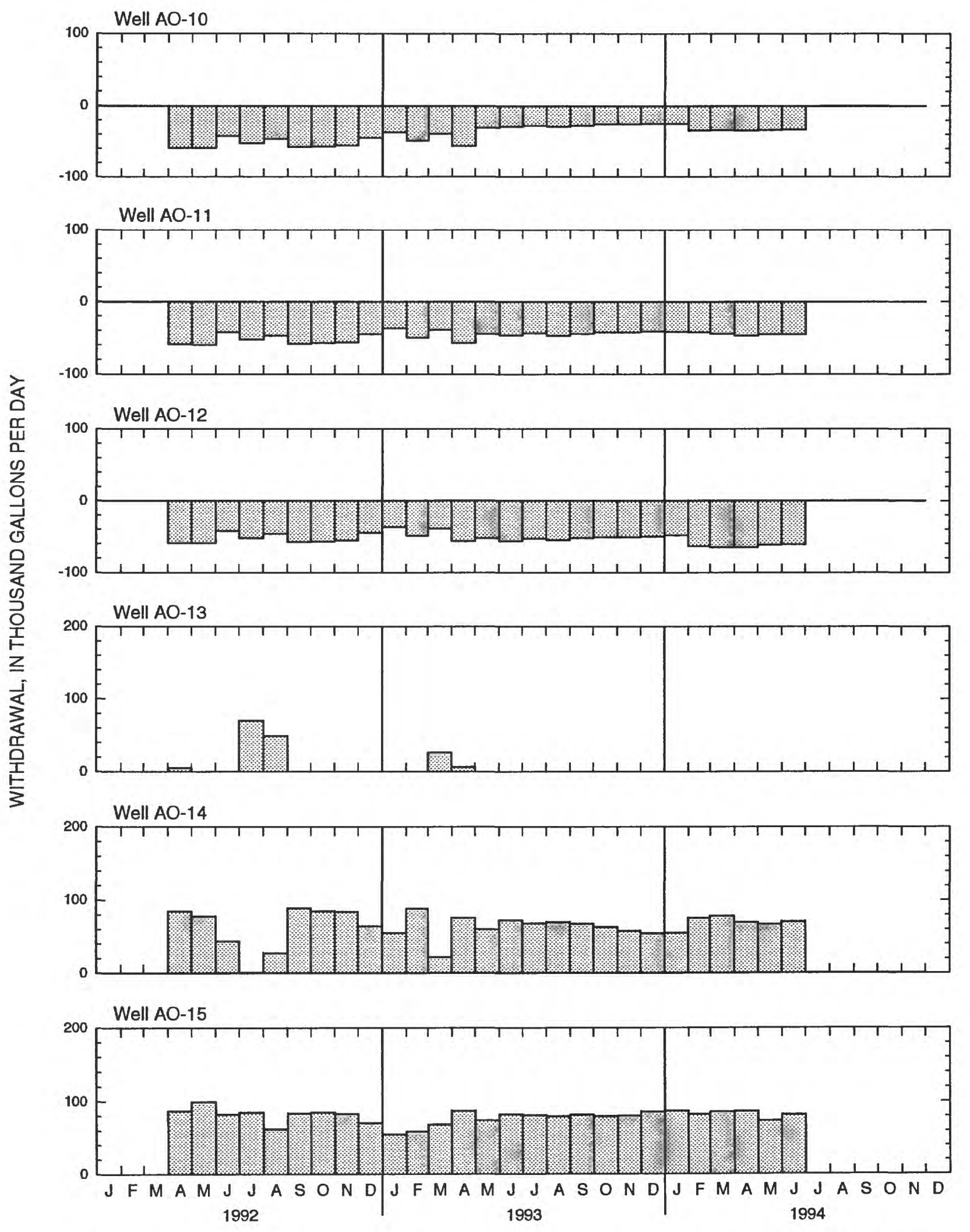

Figure 7. Monthly mean ground-water withdrawal and injection at wells AO-10 through AO-15 at Air Operations, Diego Garcia, January 1992 through June 1994. Injection is plotted as negative withdrawal. 


\title{
H Y D R O L O G I C - D A T A SECTION
}

\author{
TYPES OF DATA INCLUDED
}
A. Maps of production and monitoring wells at Cantonment and Air Operations
B. Graphs of monthly mean ground-water withdrawal, January 1992 through June 1994
C. Graphs of weekly chloride concentration of pumped water, January 1992 through June 1994

\section{DESCRIPTIONS OF PRINCIPAL PRODUCTION SOURCES AT CANTONMENT AND AIR OPERATIONS AREAS}

\section{Cantonment Area}

1. Modules A, C through $\mathrm{L}$ - each module is a well field of 5 to 8 vertical wells that pump to a common collection/transfer tank.

2. Module B is a horizontal well with a collection/transfer tank; has not pumped since August 1986.

3. Wells $\mathrm{H} 1$ through $\mathrm{H} 7$ are horizontal wells.

4. Quad wells are a well field of four vertical wells.

5. Jungle wells are a well field of 11 vertical wells; have not pumped since February 1987.

\section{Air Operations Area}

1. Wells AO-2 through AO-5 are vertical wells.

2. Wells AO-6 through AO-9 are horizontal wells.

3. Wells AO-10 through AO-12 are horizontal wells; currently receiving injection water to divert fuel contaminants from a nearby spill. No samples are currently collected for chloride concentration analysis.

4. Wells AO-13 through AO-15 are horizontal wells; AO-14 and AO-15 are currently pumping water to injection wells $\mathrm{AO}-10$ through $\mathrm{AO}-12$, while $\mathrm{AO}-13$ is not pumping.

5. AO-16 through AO-19 are horizontal wells. 


\section{SECTION A}

\section{Maps of production and monitoring wells at Cantonment and Air Operations}



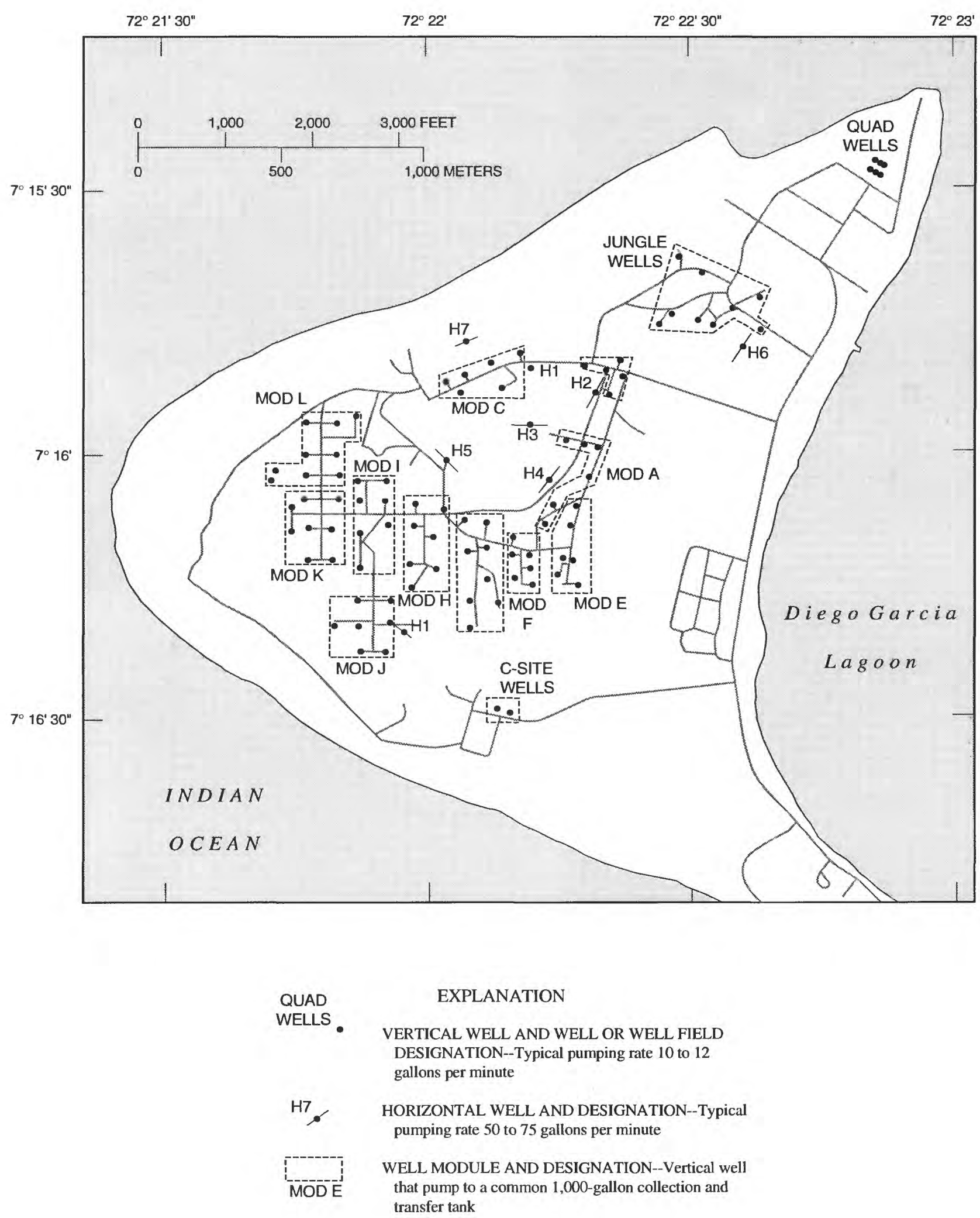

Figure A1. Ground-water production wells and well fields at Cantonment, Diego Garcia. 


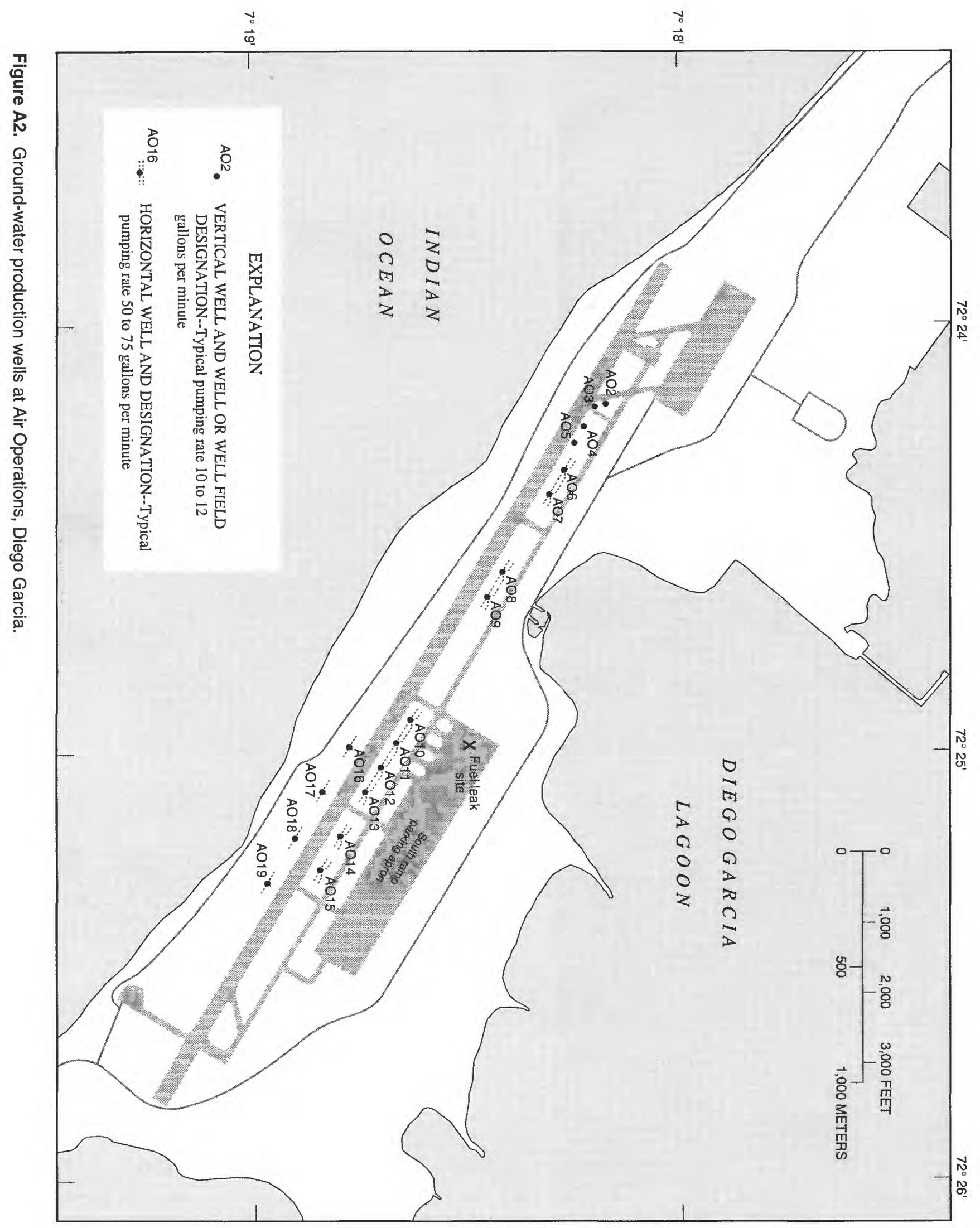




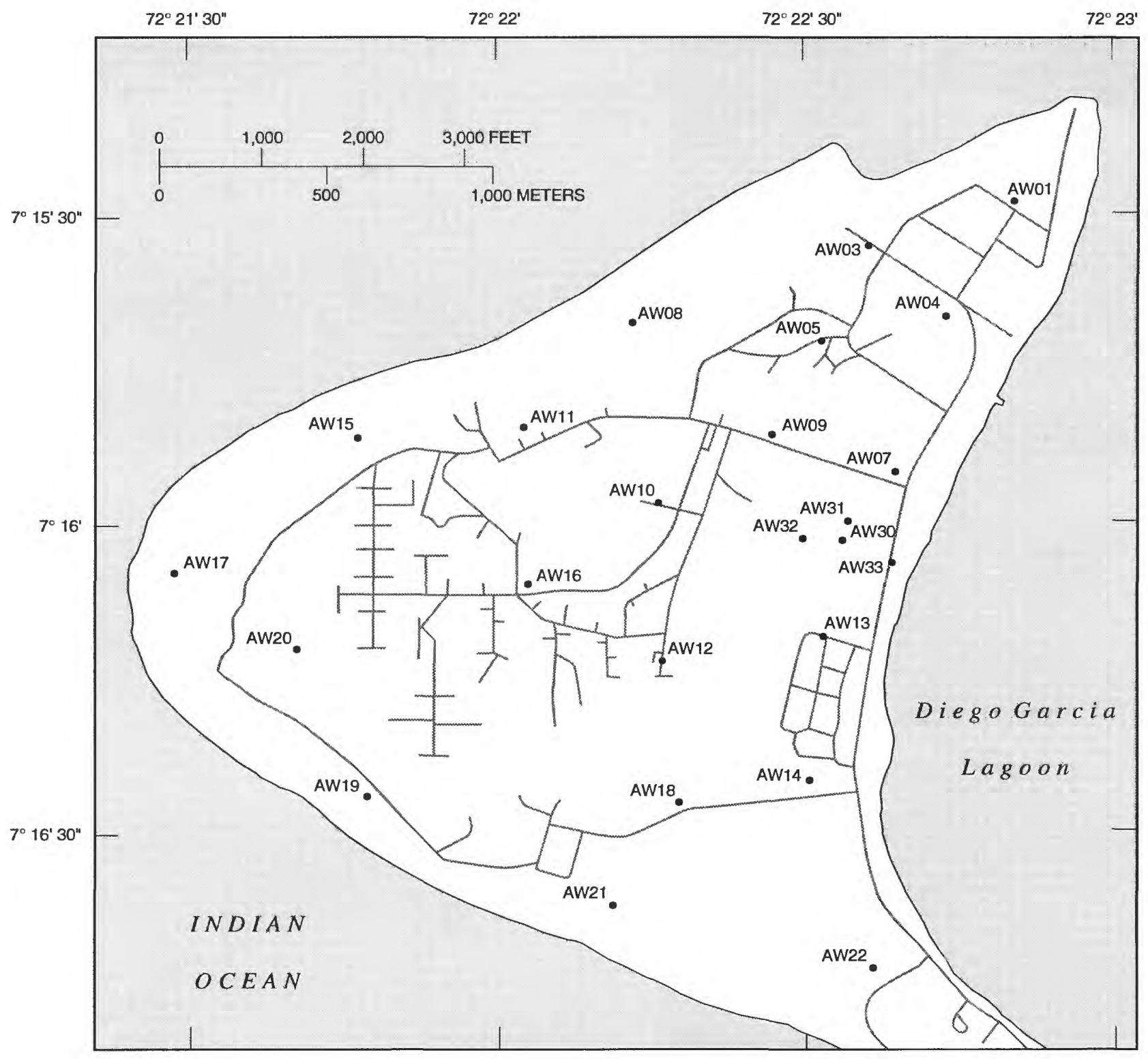

\section{EXPLANATION}

AW21 MONITORING SITE AND DESIGNATION--Consisting of two or more monitoring wells with short (2 to 5 foot) open intervals of different depths

Figure A3. Monitoring wells at Cantonment, Diego Garcia. 


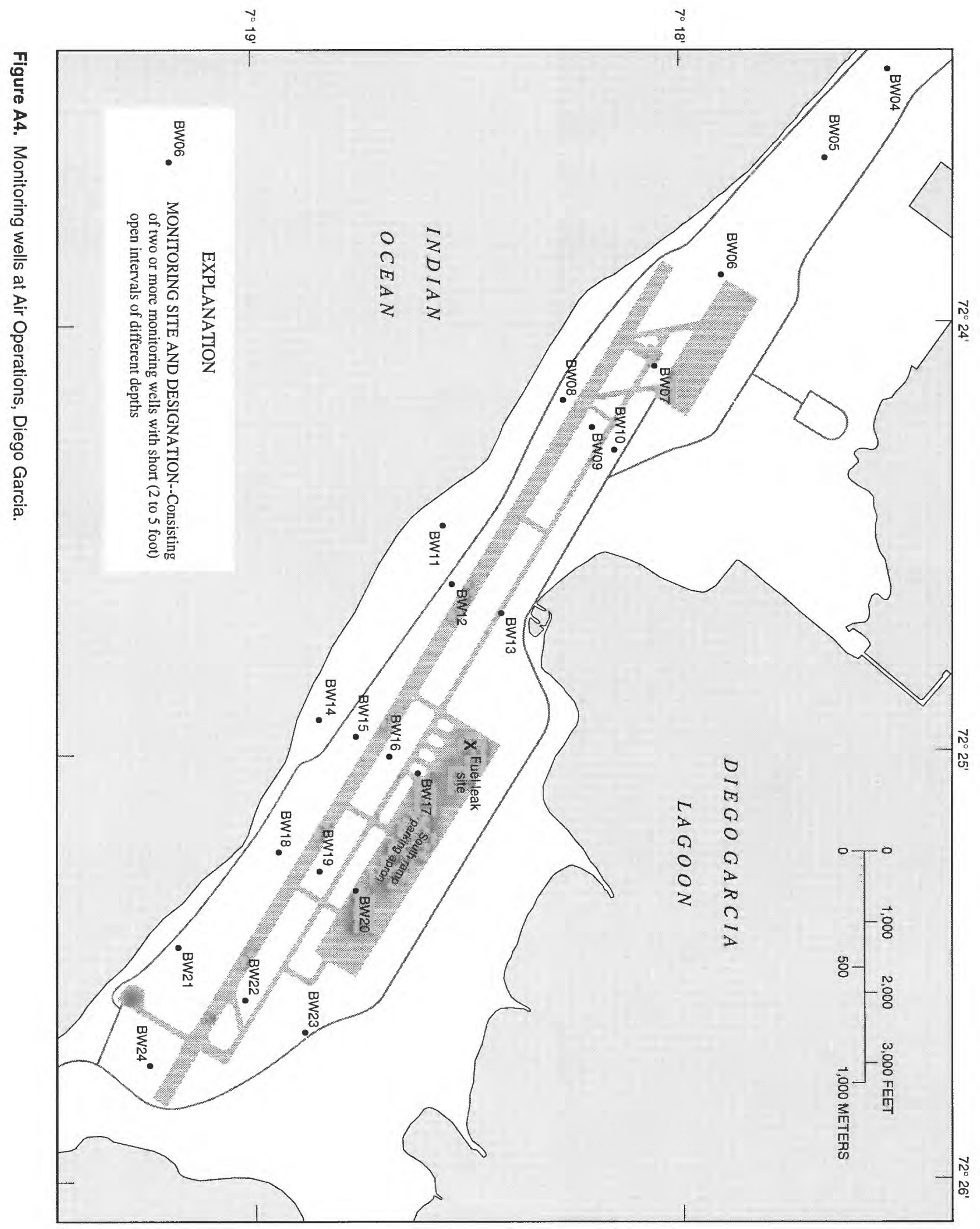




\section{SECTION B}

Graphs of monthly mean ground-water withdrawal, January 1992 through June 1994 

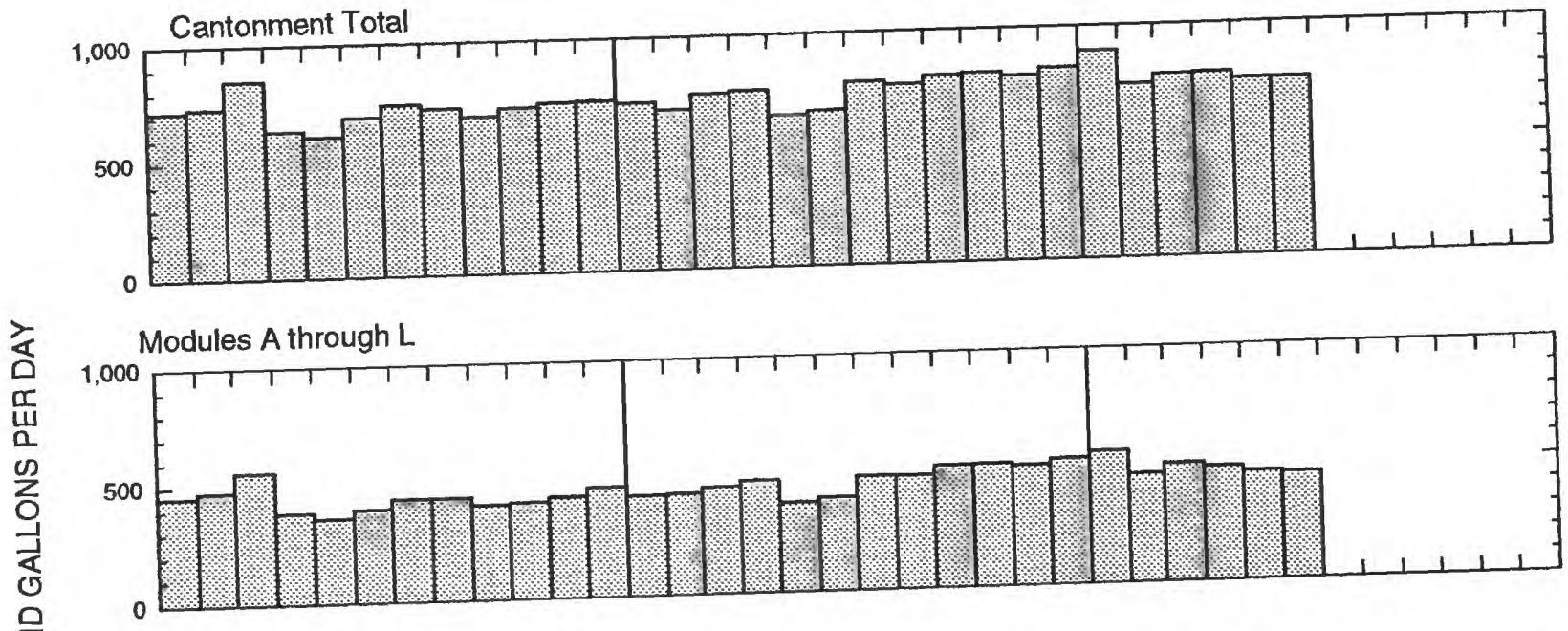

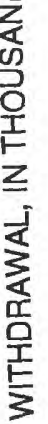

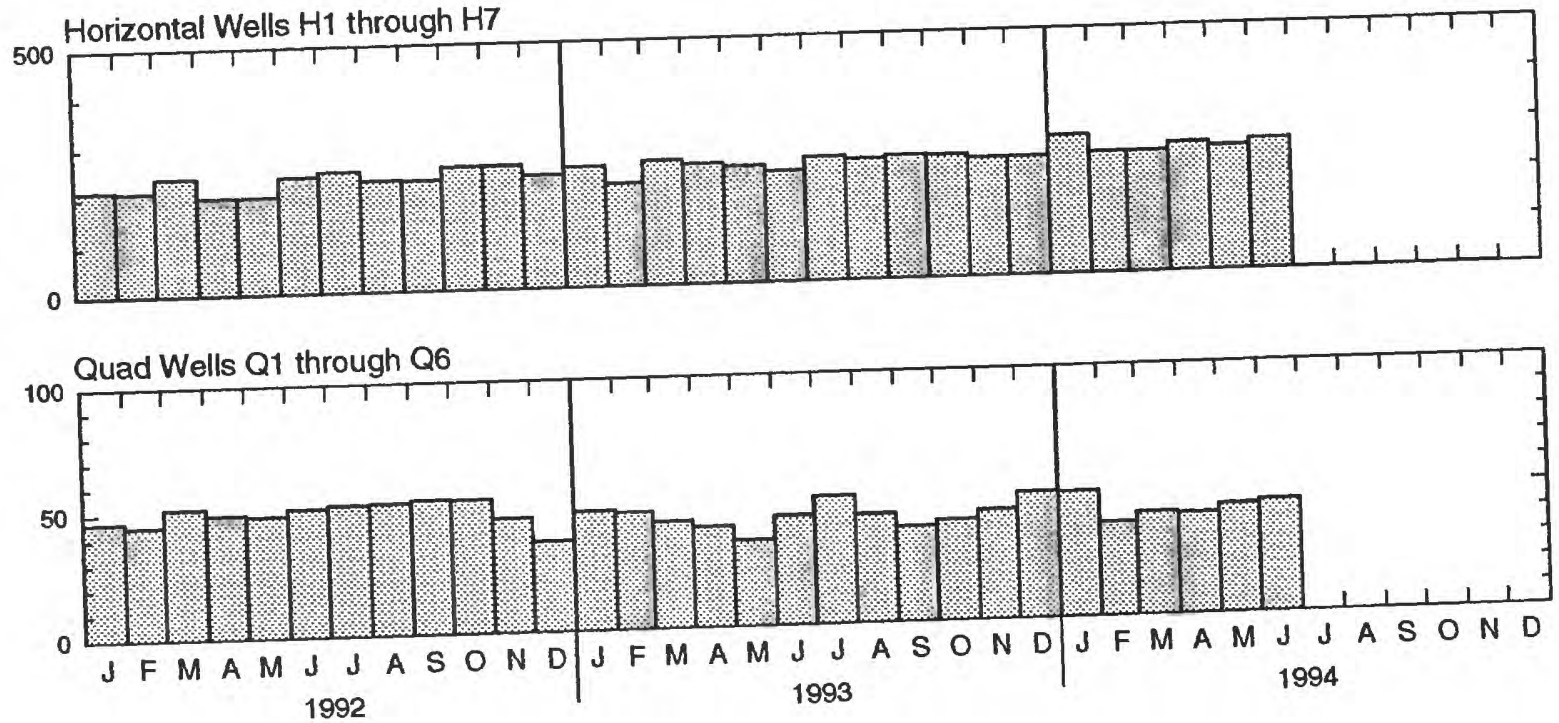

Figure B1. Monthly mean ground-water withdrawal at Cantonment, Diego Garcia, January 1992 through June 1994. 

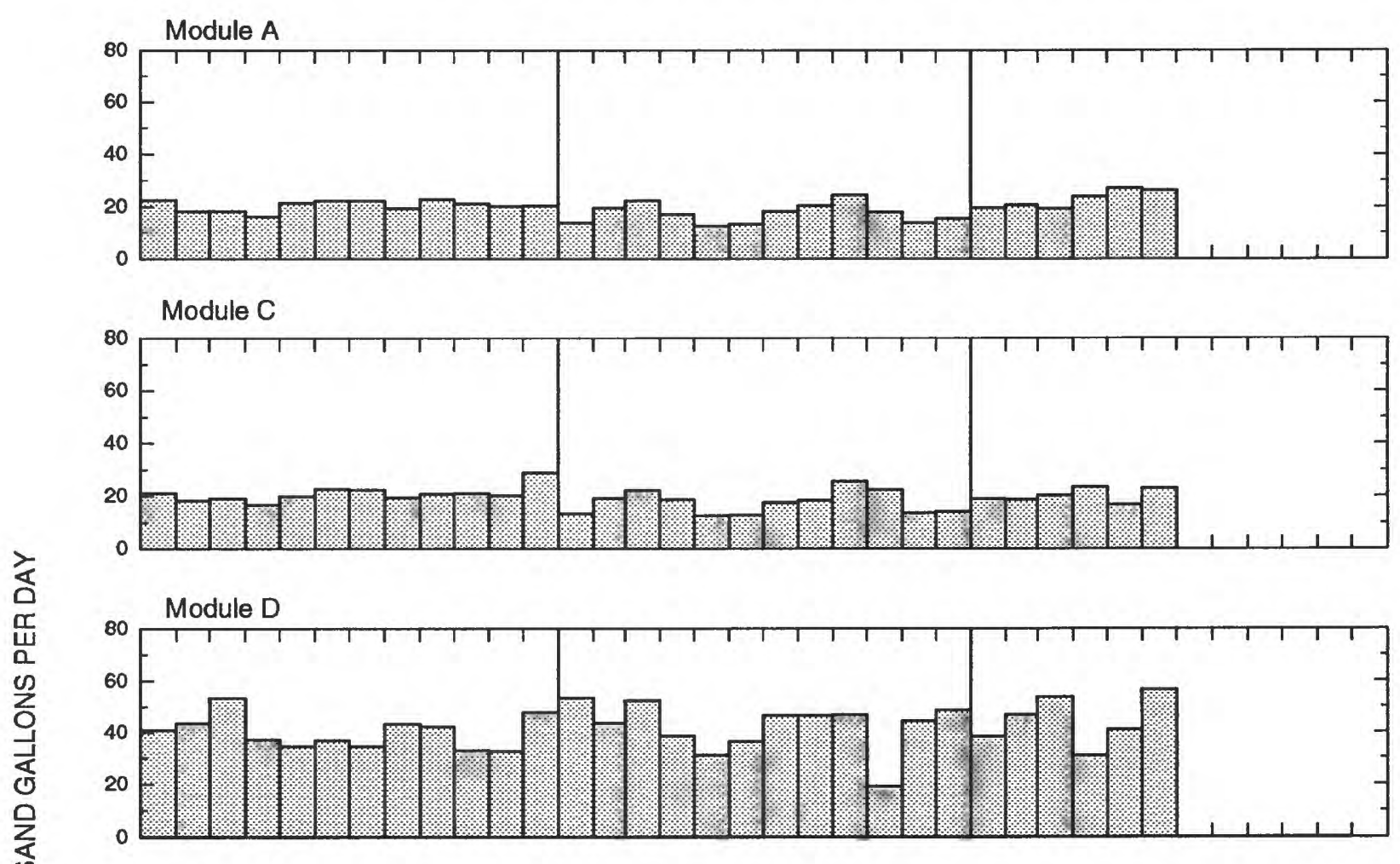

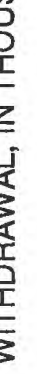
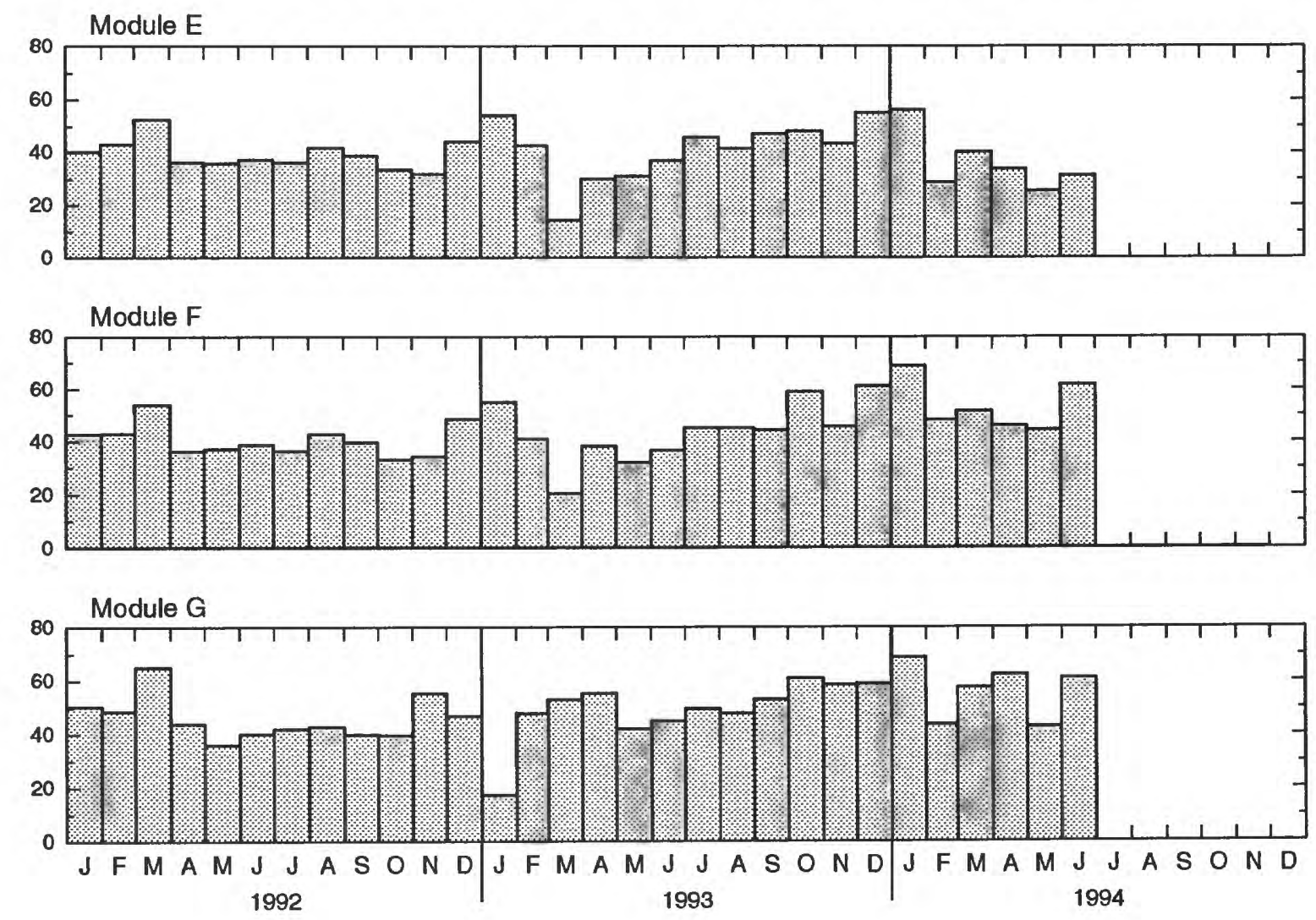

Figure B2. Monthly mean ground-water withdrawal at Modules A through L at Cantonment, Diego Garcia, January 1992 through June 1994. 

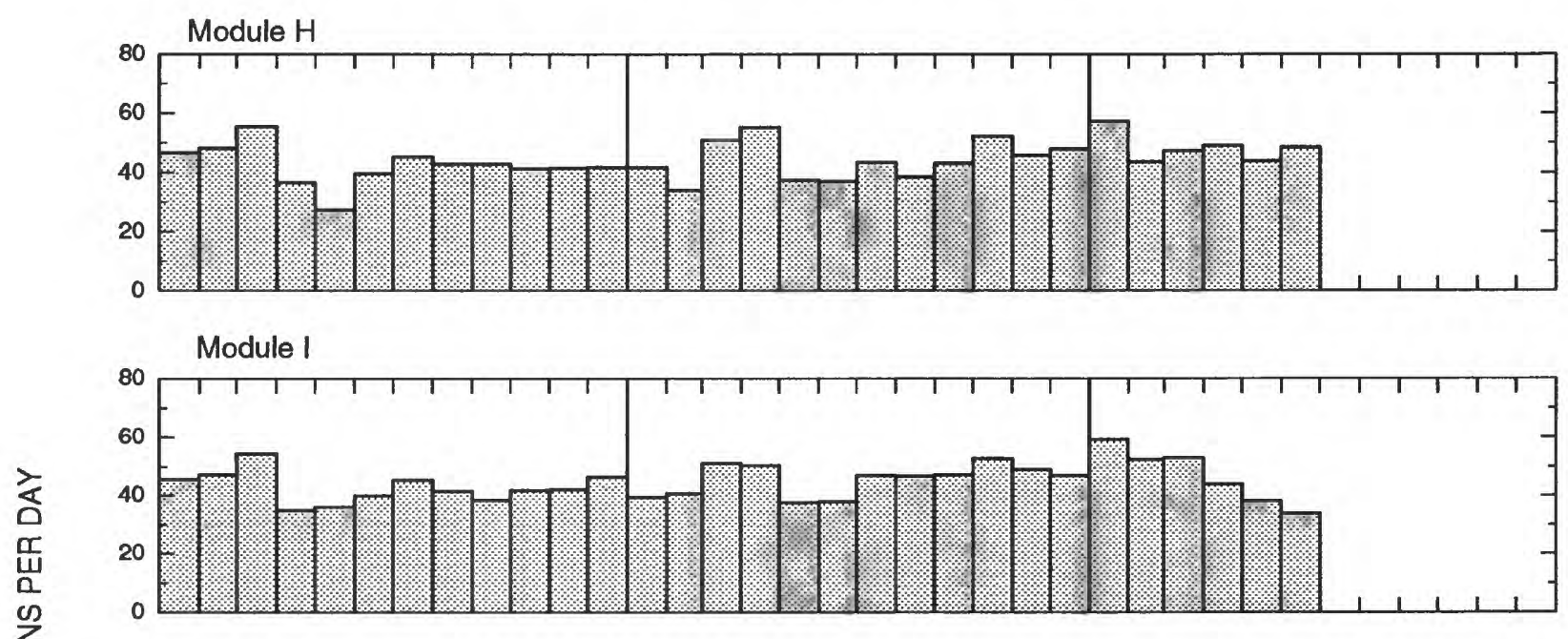

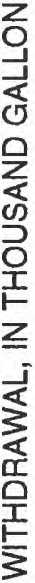
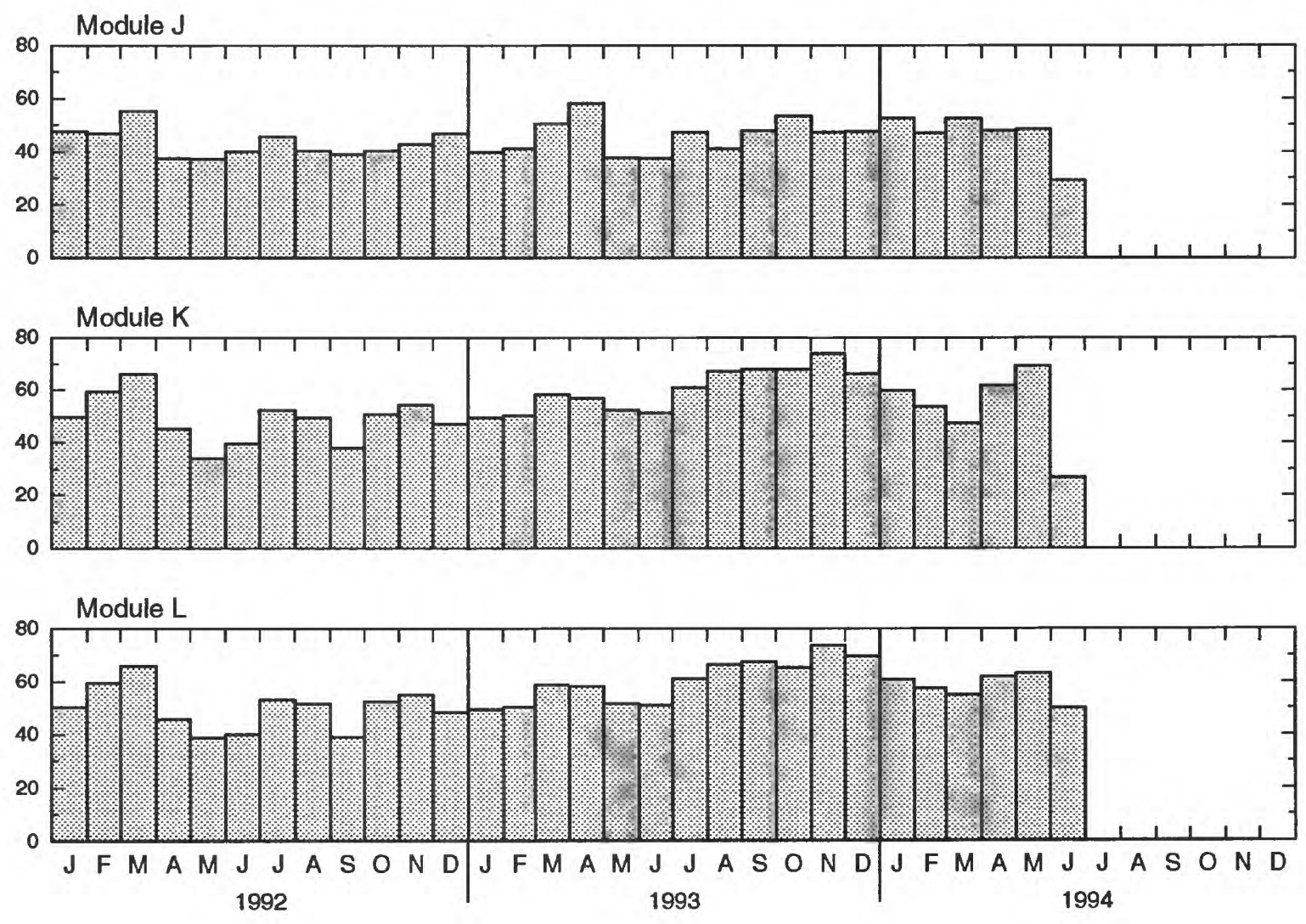

Figure B2 continued.--Monthly mean ground-water withdrawal at Modules A through L at Cantonment, Diego Garcia, January 1992 through June 1994. 

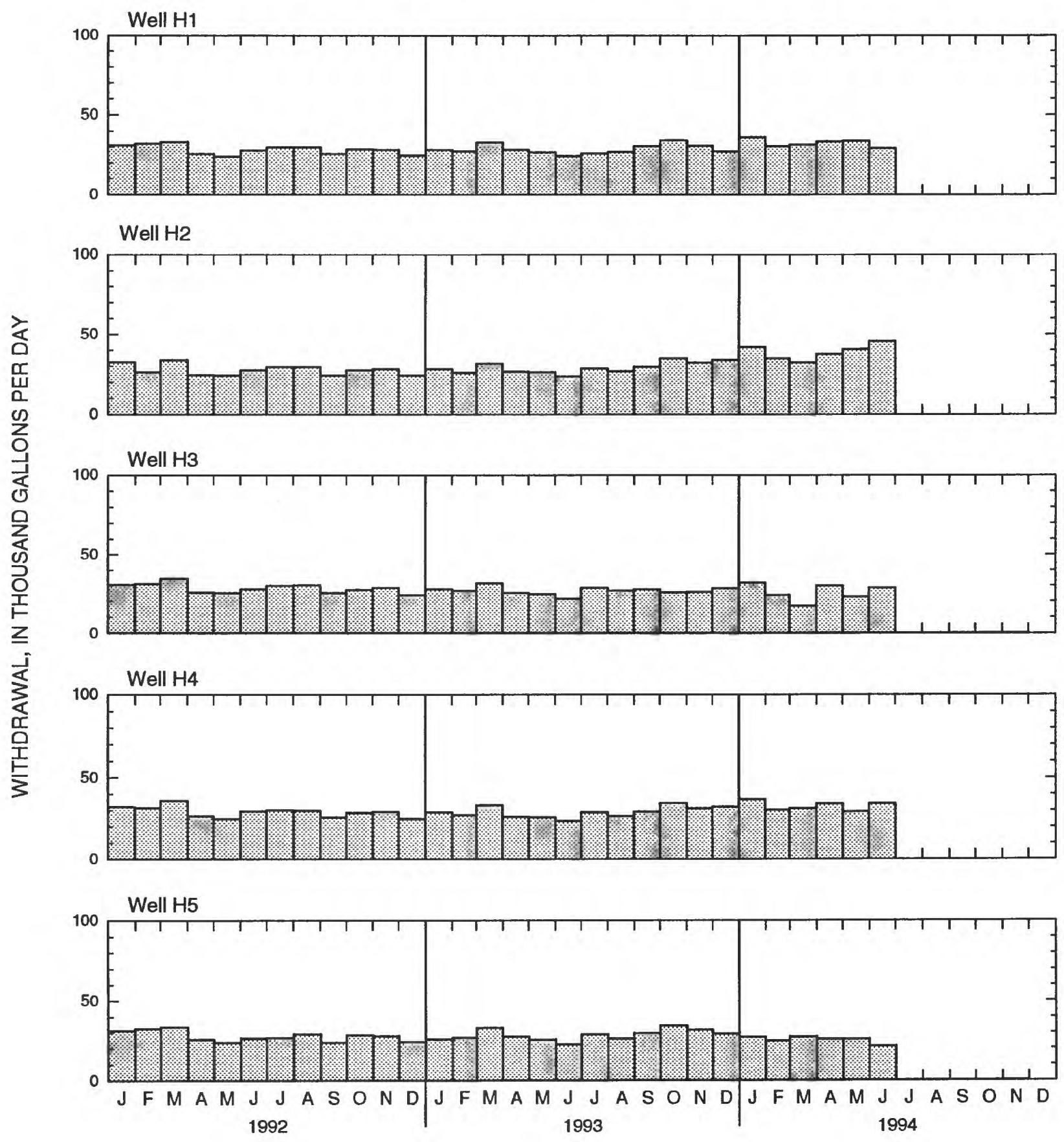

Figure B3. Monthly mean ground-water withdrawal at wells H1 through $\mathrm{H} 7$ at Cantonment, Diego Garcia, January 1992 through June 1994. 


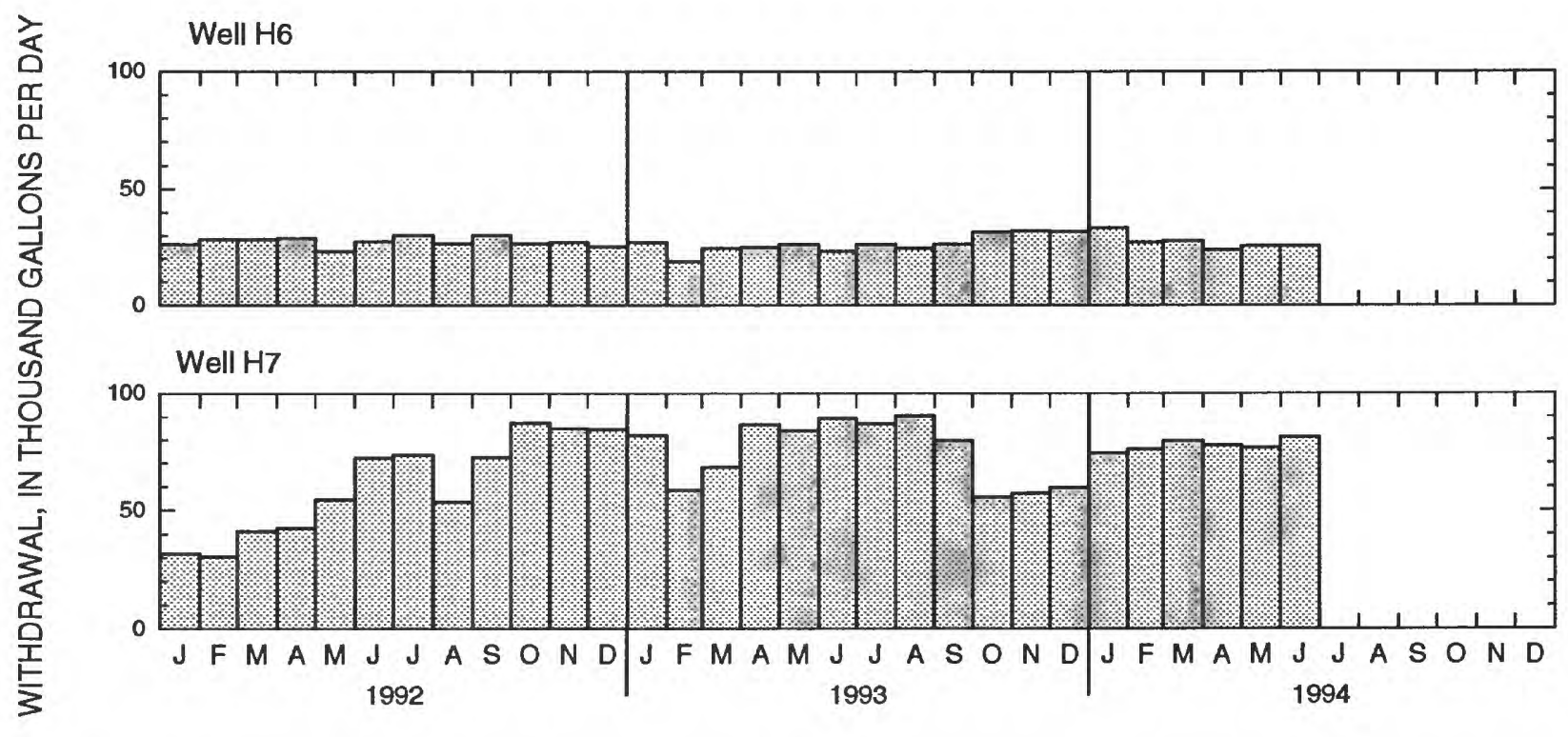

Figure B3 continued.--Monthly mean ground-water withdrawal at wells $\mathrm{H} 1$ through $\mathrm{H} 7$ at Cantonment, Diego Garcia, January 1992 through June 1994. 


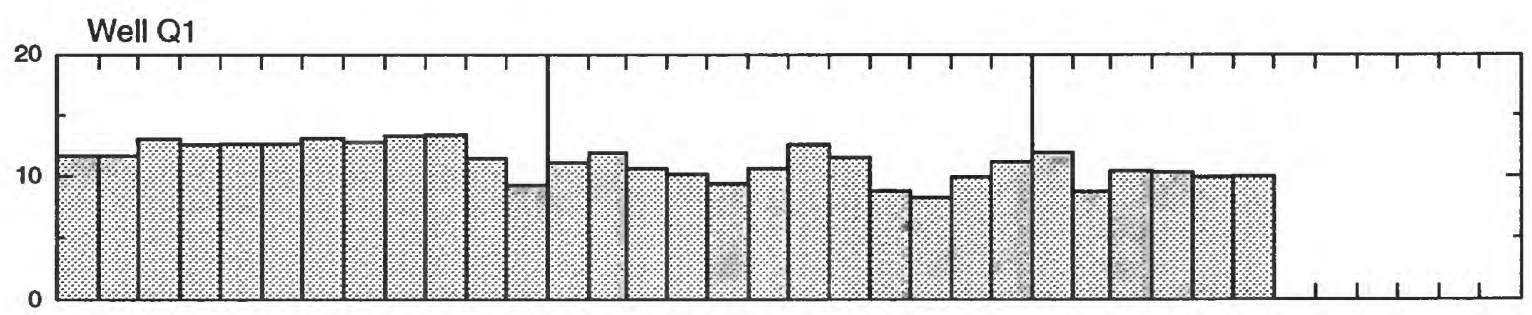

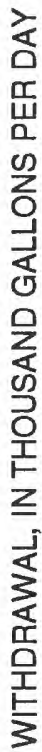
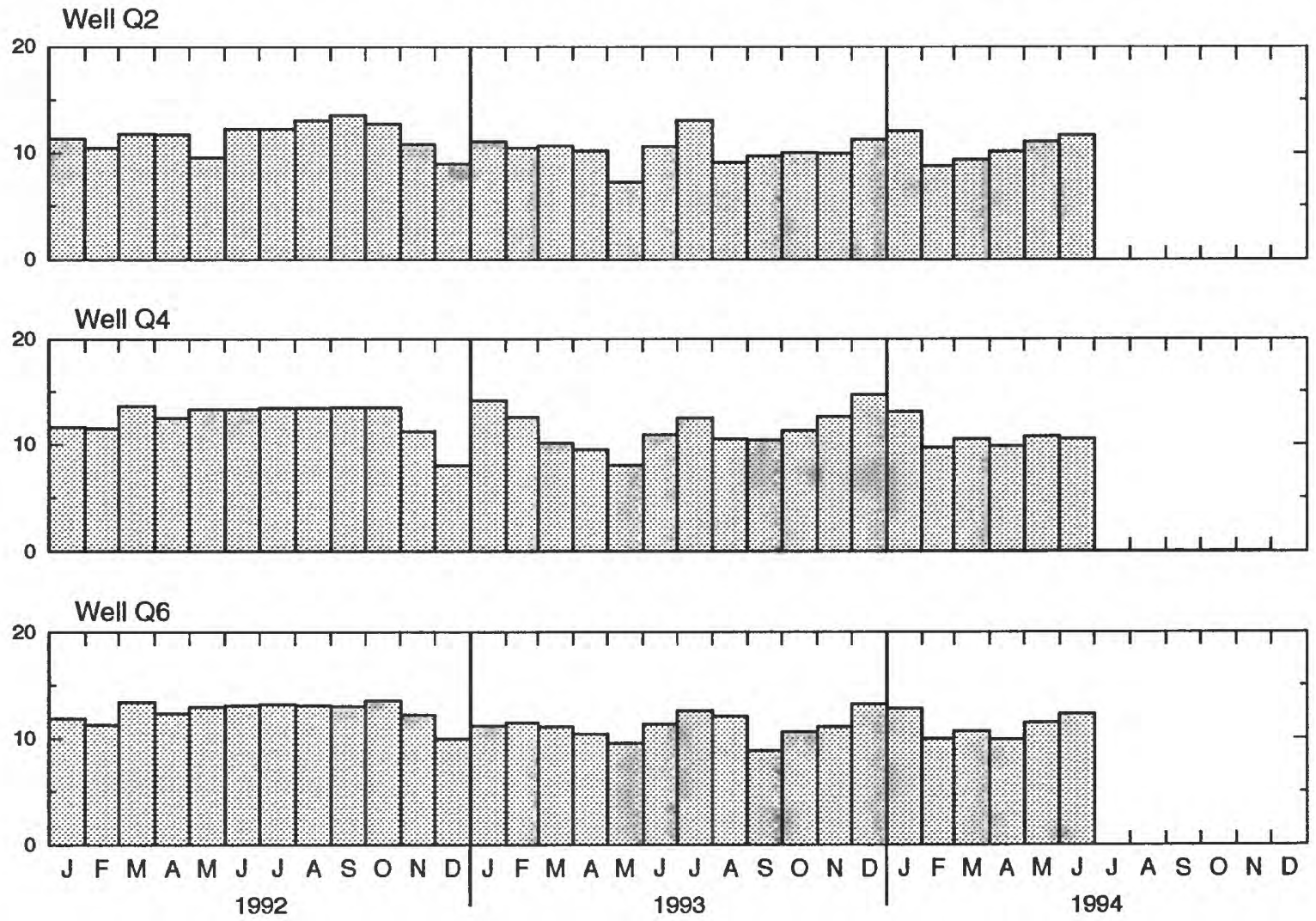

Figure B4. Monthly mean ground-water withdrawal at wells Q1, Q2, Q4, and Q6 at Cantonment, Diego Garcia, January 1992 through June 1994. 

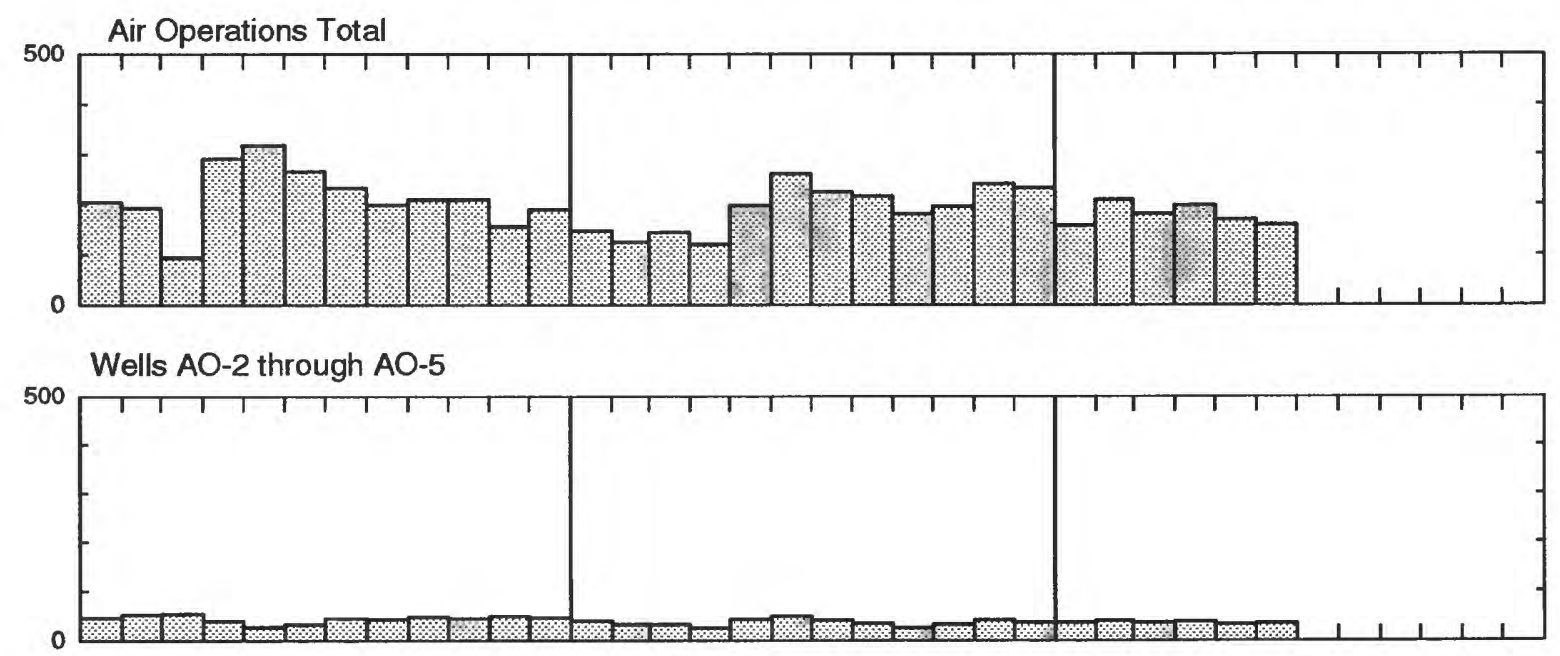

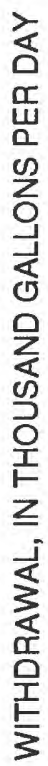
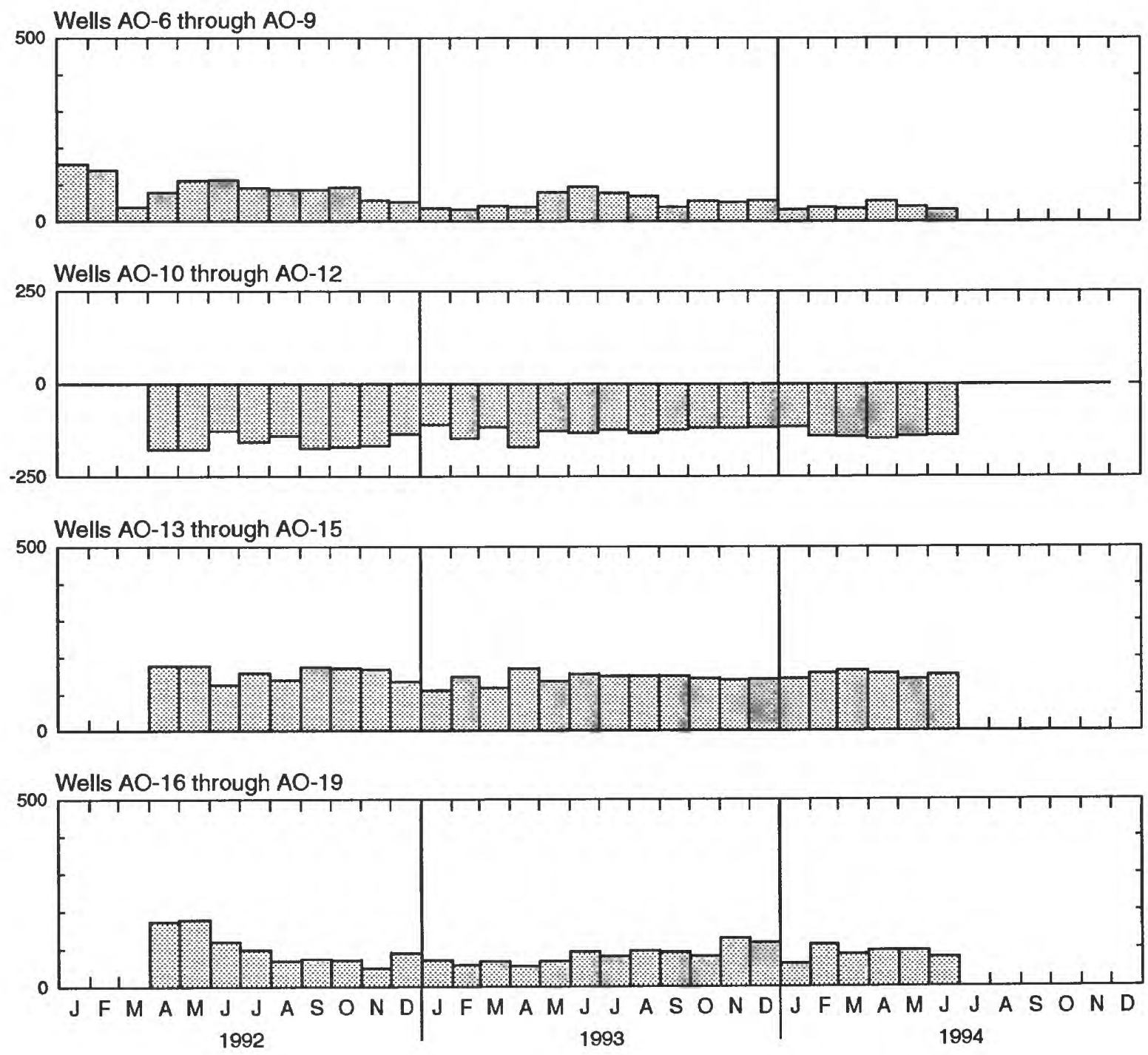

Figure B5. Monthly mean ground-water withdrawal and injection at Air Operations, Diego Garcia, January 1992 through June 1994. Injection is plotted as negative withdrawal. 


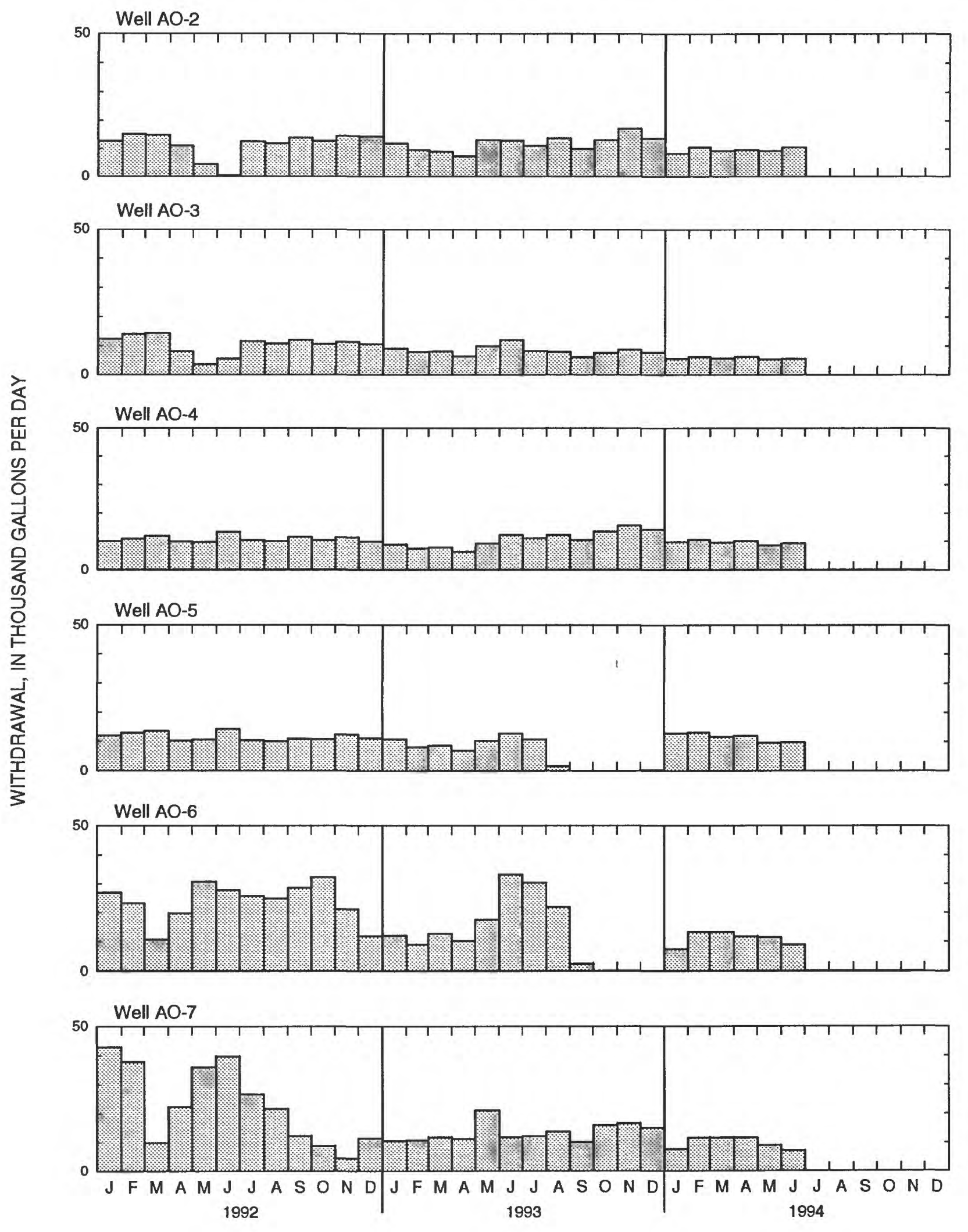

Figure B6. Monthly mean ground-water withdrawal and injection at wells AO-2 through AO-19 at Air Operations, Diego Garcia, January 1992 through June 1994. Injection is plotted as negative withdrawal. 


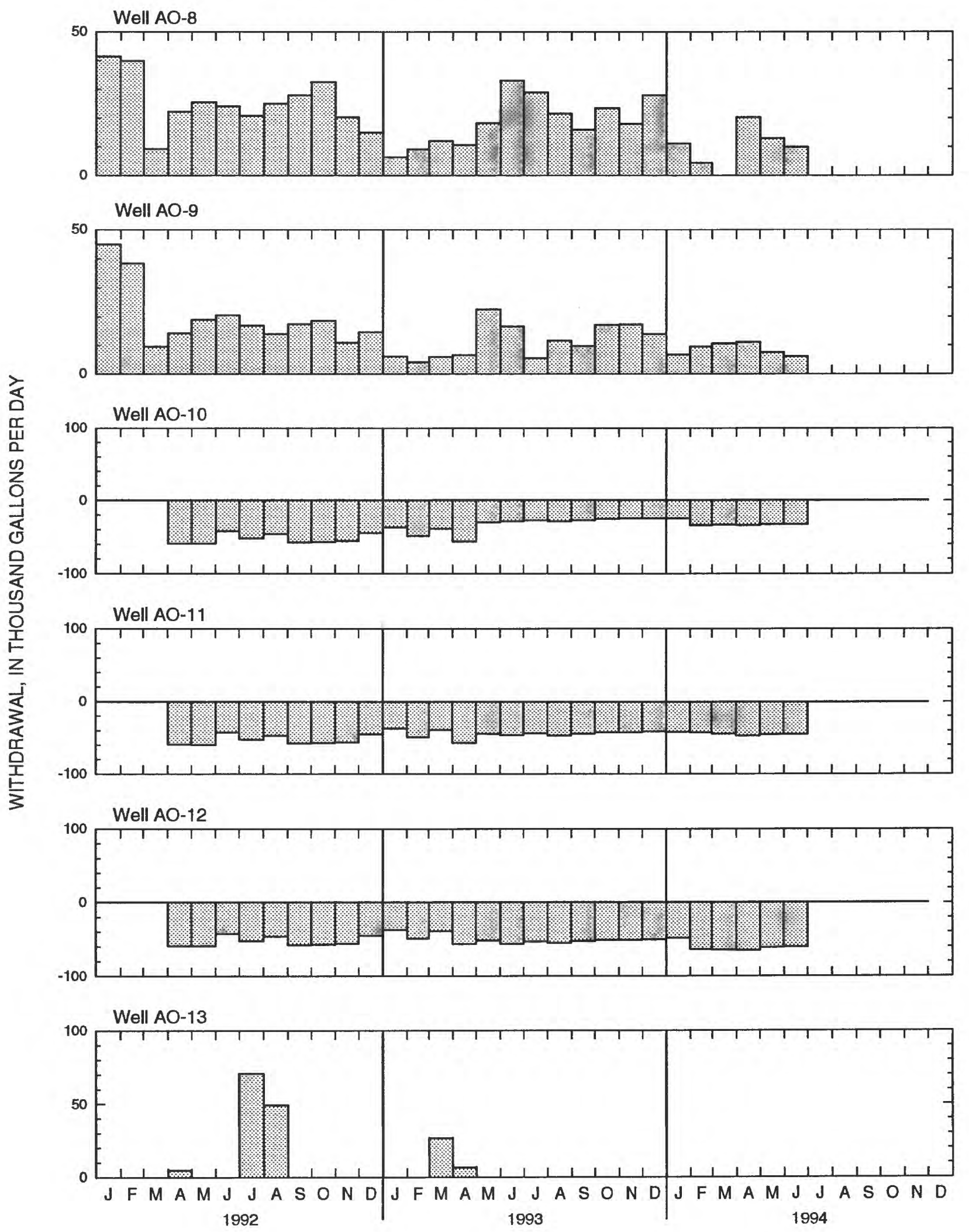

Figure B6 continued.--Monthly mean ground-water withdrawal and injection at wells AO-2, through AO-19 at Air Operations, Diego Garcia, January 1992 through June 1994. Injection is plotted as negative withdrawal. 

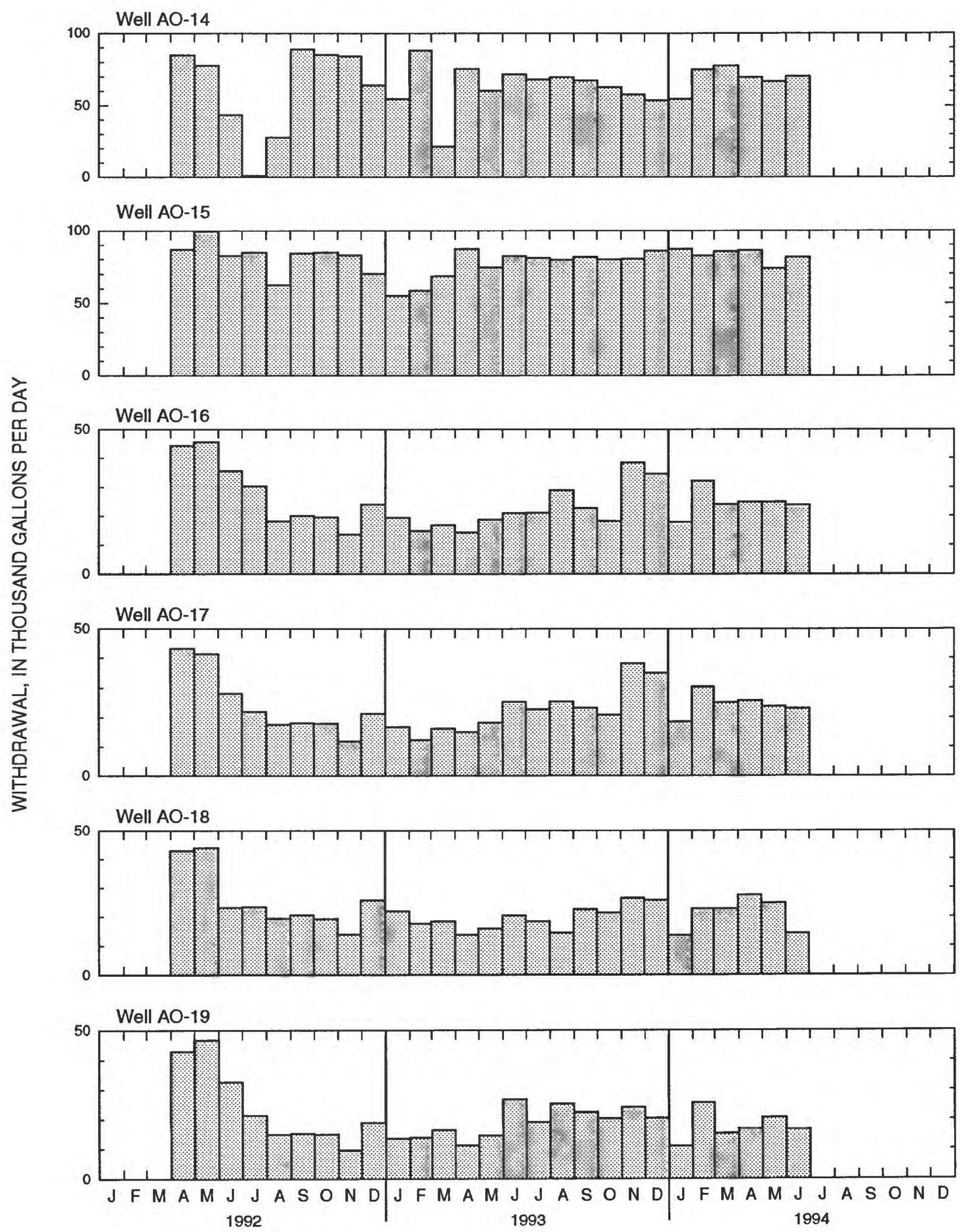

Figure B6 continued.--Monthly mean ground-water withdrawal and injection at wells AO-2 through AO-19 at Air Operations, Diego Garcia, January 1992 through June 1994. Injection is plotted as negative withdrawal. 


\section{SECTION C}

Graphs of weekly chloride concentration of pumped water, January 1992 through June 1994 

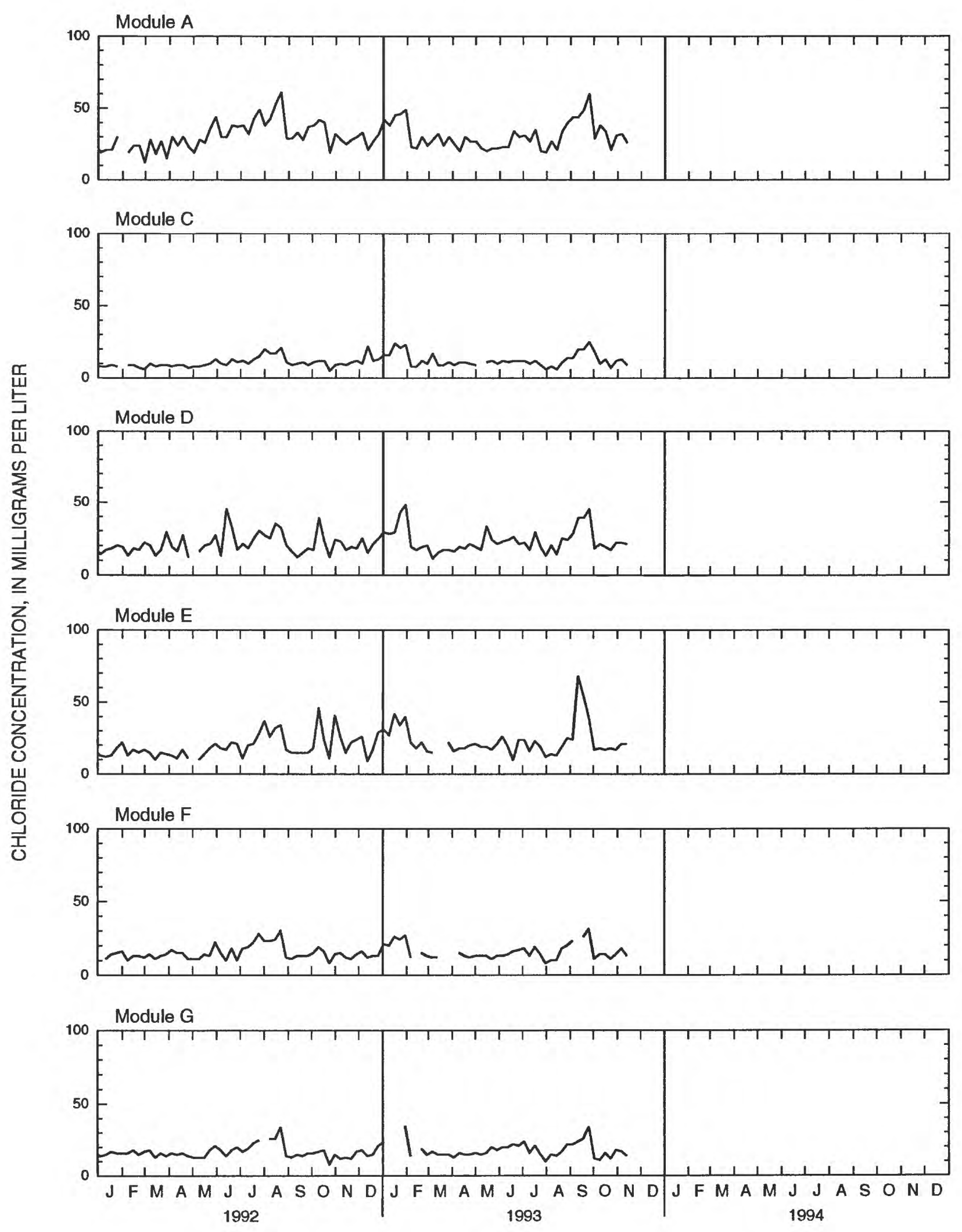

Figure C1. Weekly chloride concentration of pumped water at Modules A through $\mathrm{L}$ at Cantonment, Diego Garcia, January 1992 through June 1994. Data not available since mid-November 1993. 

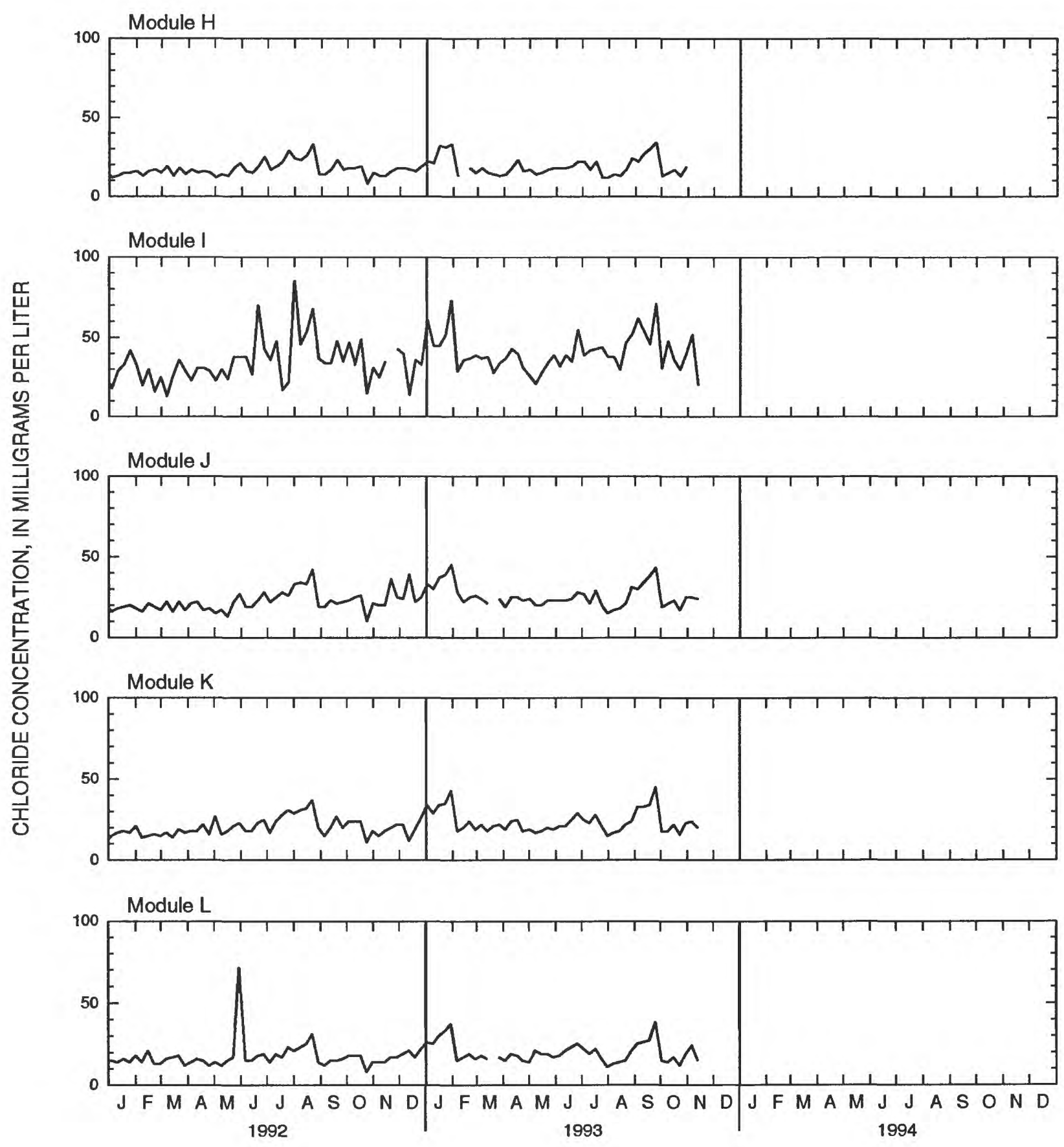

Figure $\mathrm{C} 1$ continued.--Weekly chloride concentration of pumped water at Modules A through $\mathrm{L}$ at Cantonment, Diego Garcia, January 1992 through June 1994. Data not available since mid-November 1993. 

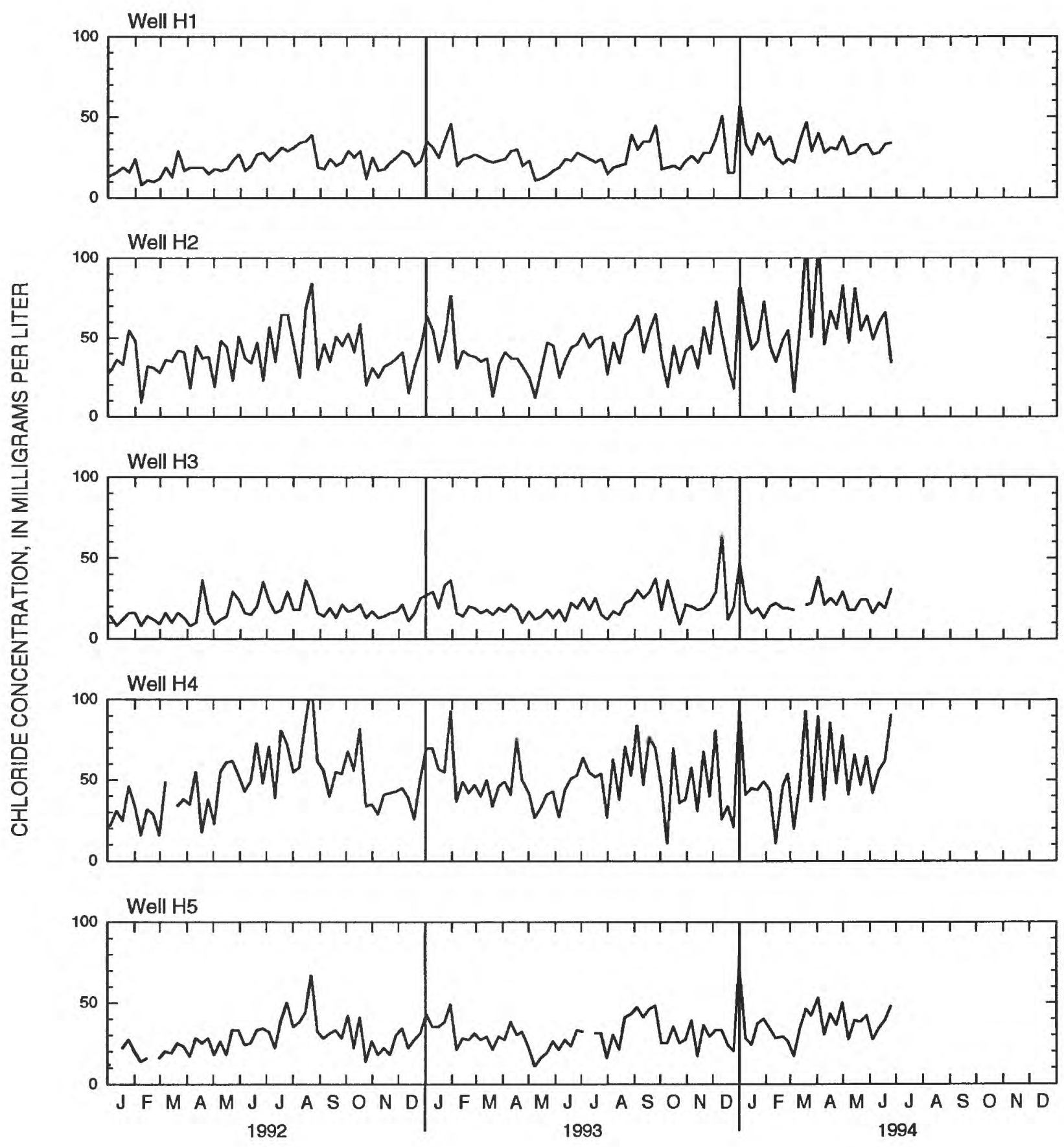

Figure C2. Weekly chloride concentration of pumped water at wells $\mathrm{H} 1$ through $\mathrm{H} 7$ at Cantonment, Diego Garcia, January 1992 through June 1994. 

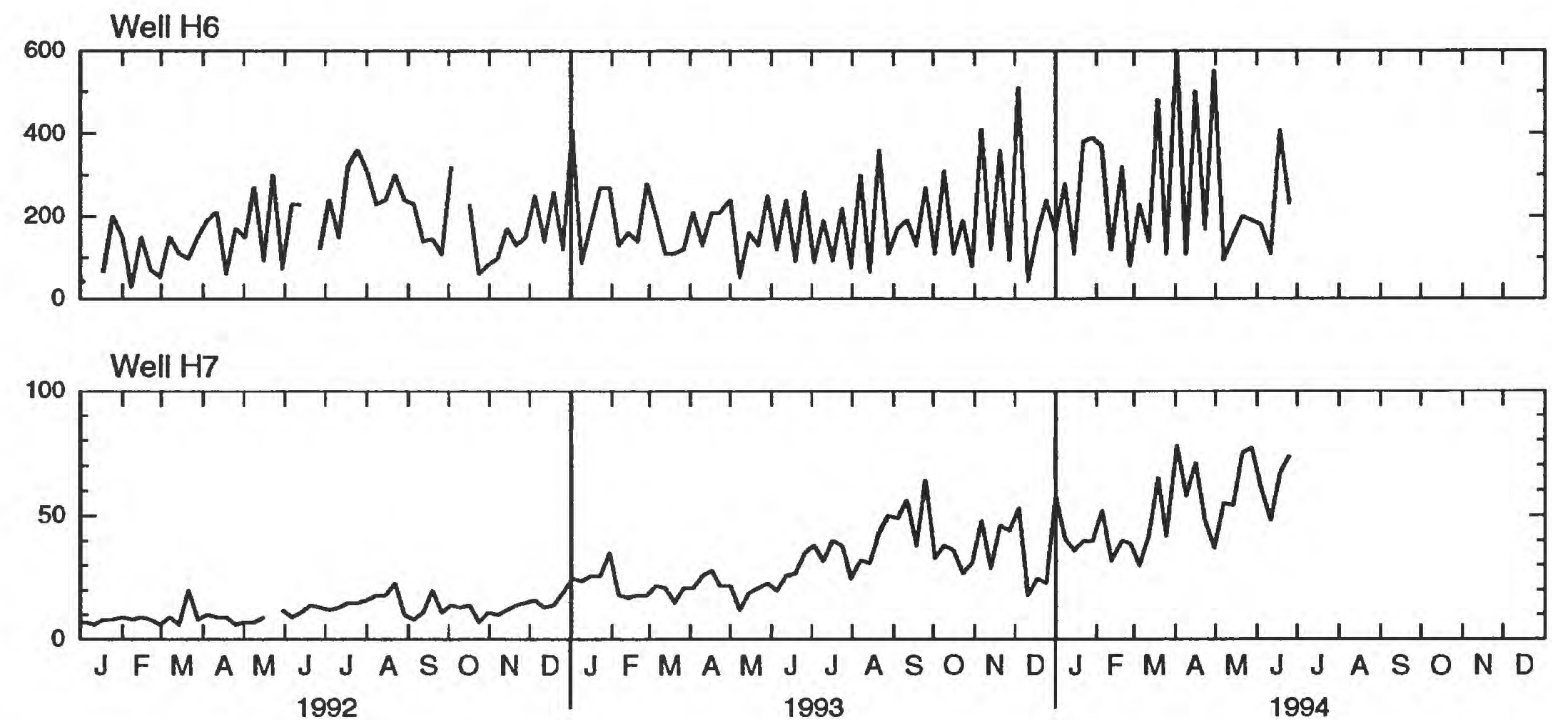

Figure $\mathrm{C} 2$ continued.--Weekly chloride concentration of pumped water at wells $\mathrm{H} 1$ through $\mathrm{H} 7$ at Cantonment, Diego Garcia, January 1992 through June 1994. 


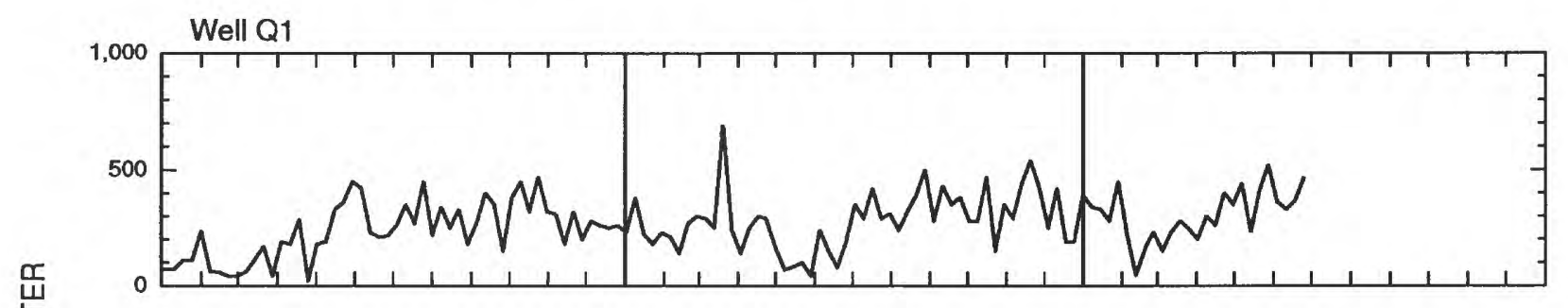

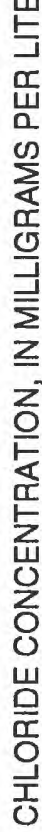
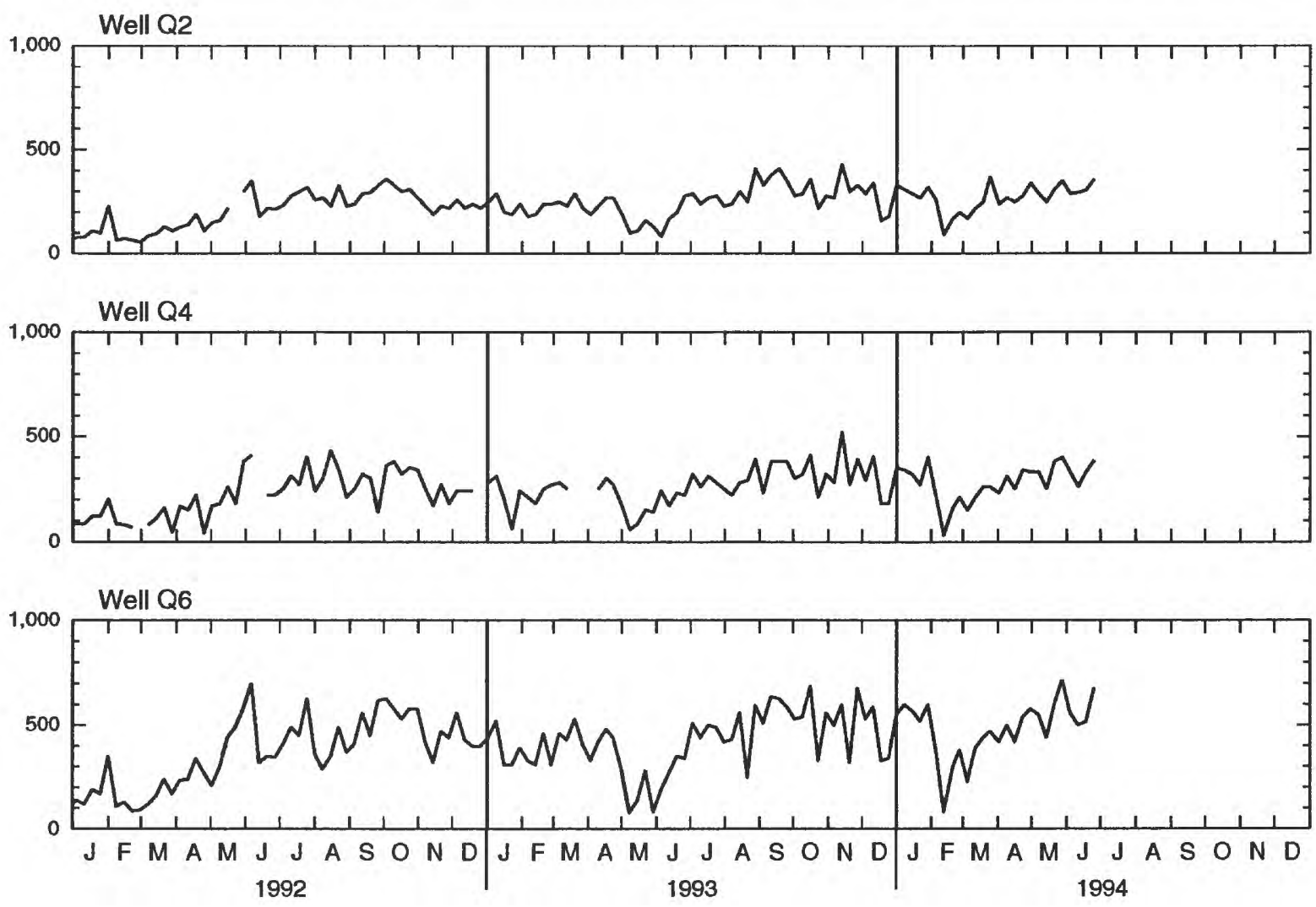

Figure C3. Weekly chloride concentration of pumped water at wells Q1, Q2, Q4, and Q6 at Cantonment, Diego Garcia, January 1992 through June 1994. 
Well AO-2
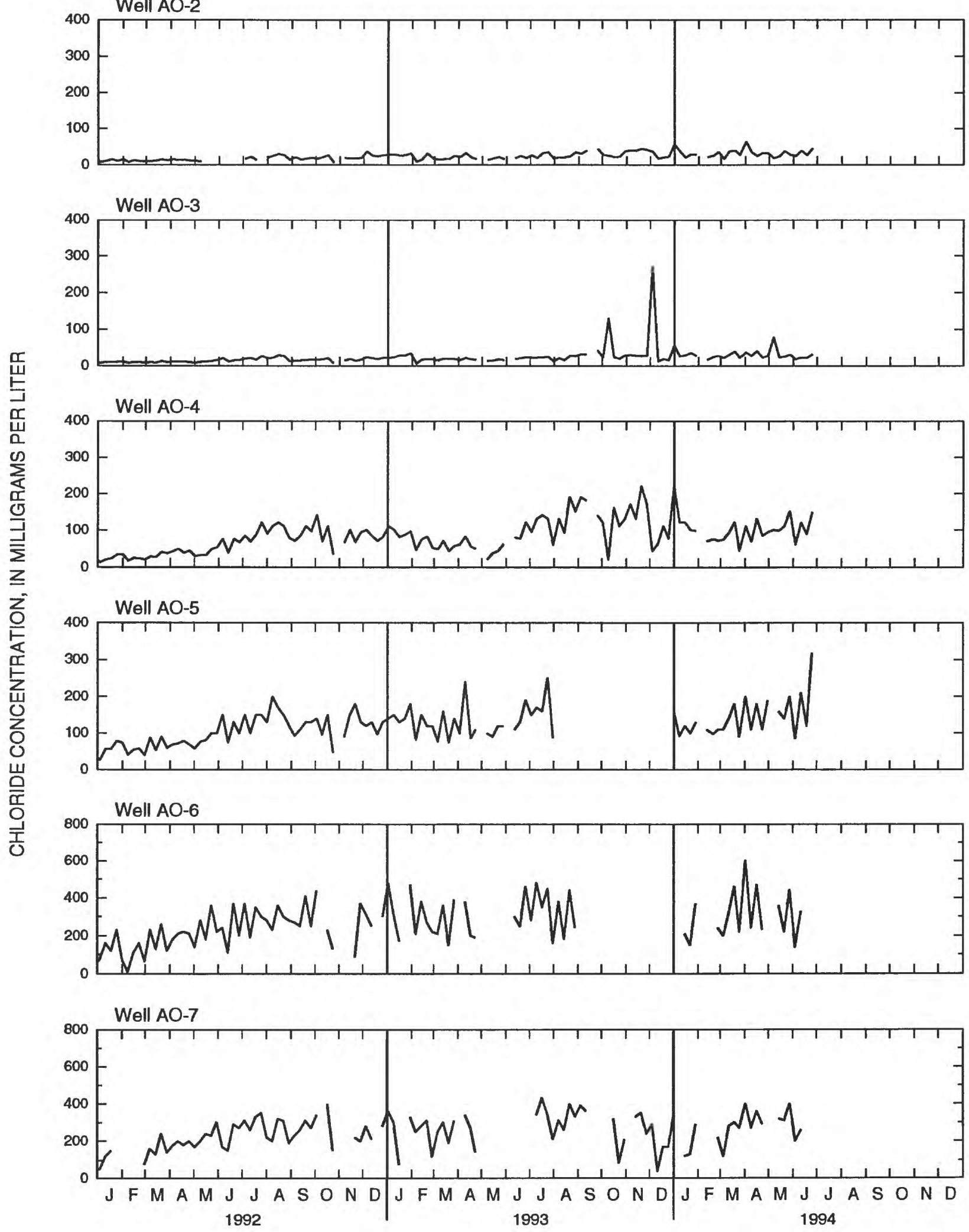

Figure C4. Weekly chloride concentration of pumped water at wells AO-2 through AO-19 at Air Operations, Diego Garcia, January 1992 through June 1994. 
Well AO-8
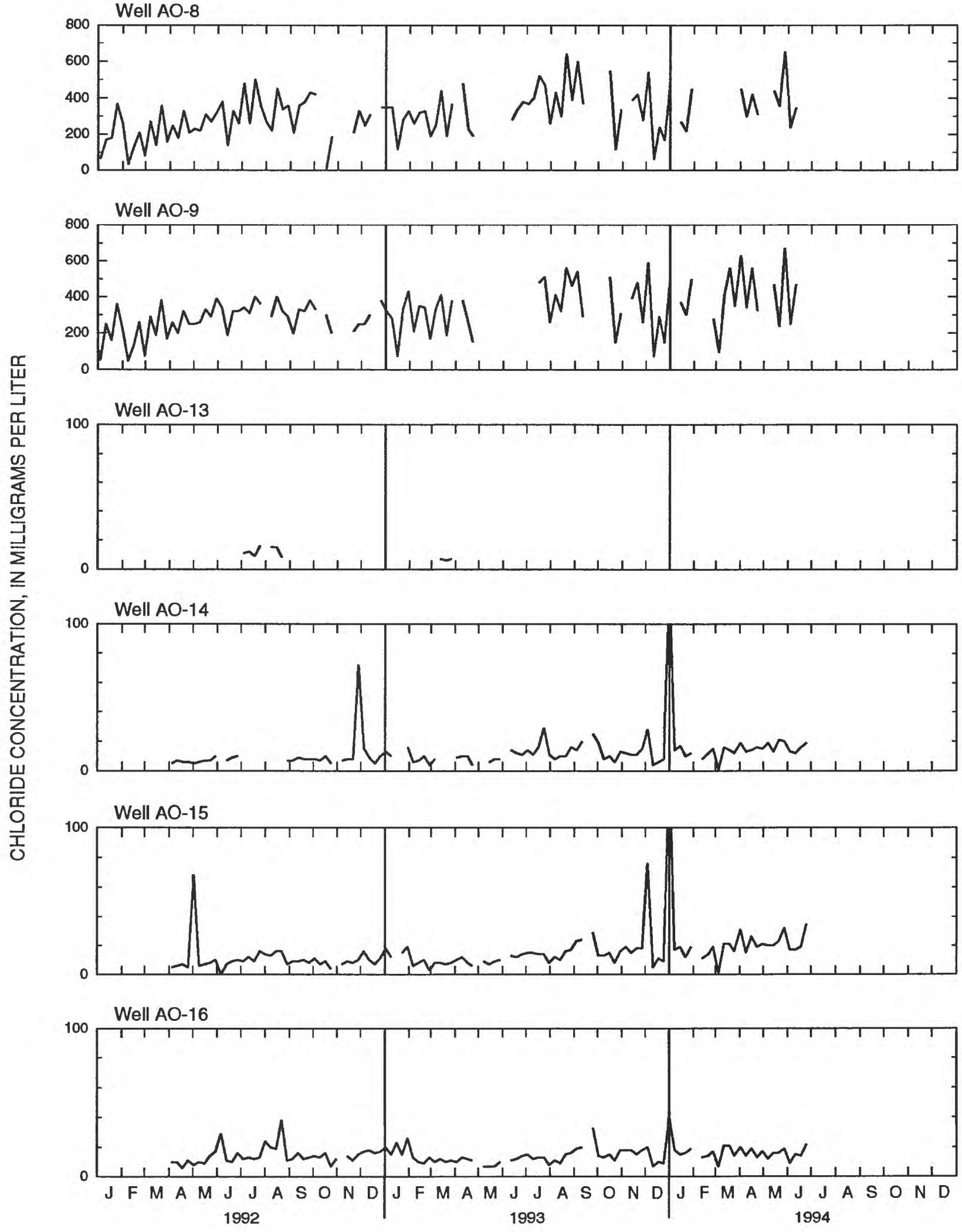

Figure C4 continued.--Weekly chloride concentration of pumped water at wells AO-2 through AO-19 at Air Operations, Diego Garcia, January 1992 through June 1994. 


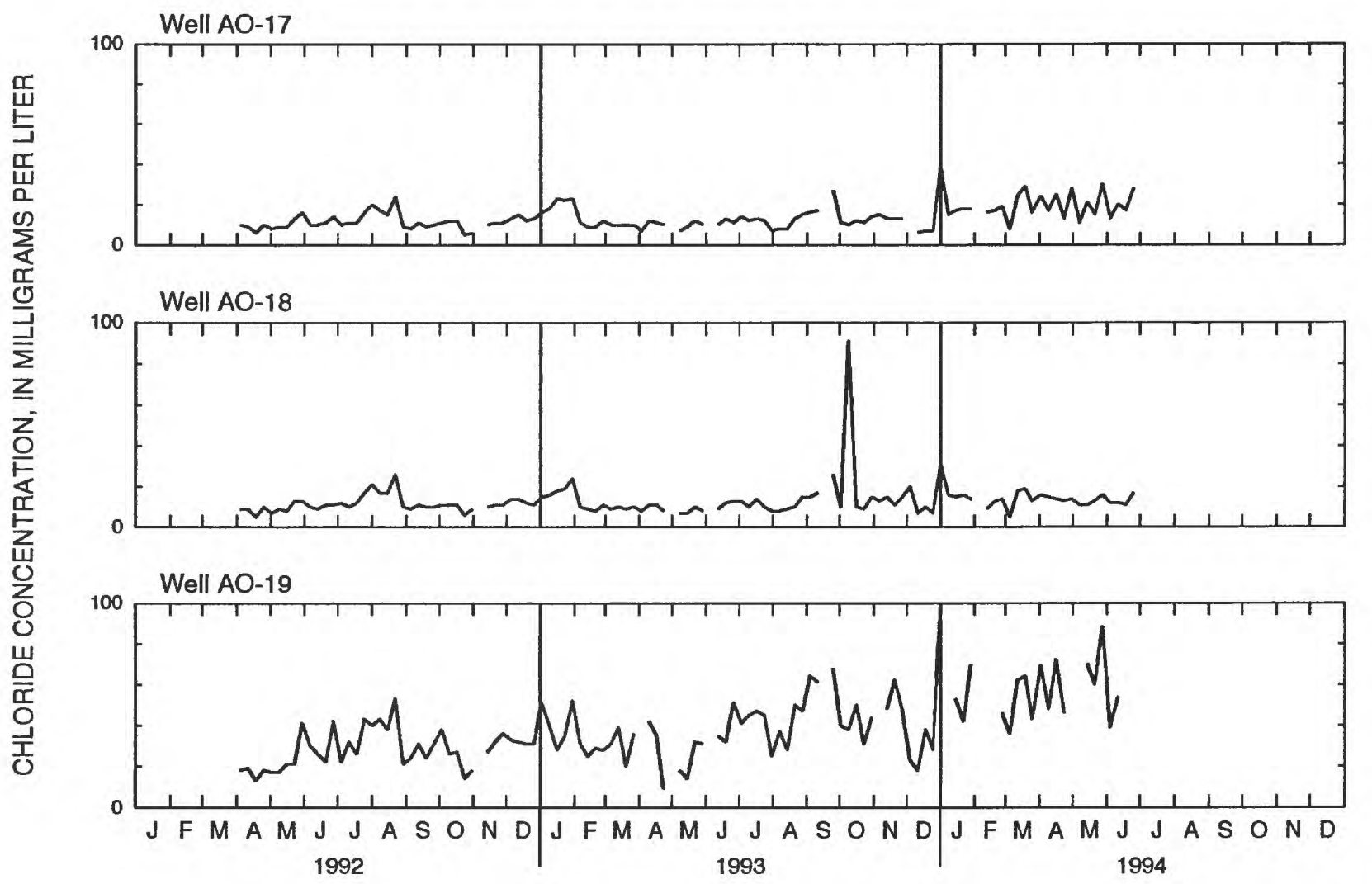

Figure C4 continued.--Weekly chloride concentration of pumped water at wells AO-2 through AO-19 at Air Operations, Diego Garcia, January 1992 through June 1994.

41 